\title{
Ground-Water Quality Data from the Abbotsford- Sumas Aquifer of Southwestern British Columbia and Northwestern Washington State, February 1997
}

\author{
By Stephen E. Cox* and Hugh Liebscher** \\ * U.S. Geological Survey \\ ** Environment Canada
}

U.S. GEOLOGICAL SURVEY

Open-File Report 99-244

Prepared jointly with

ENVIRONMENT CANADA 


\section{U.S. DEPARTMENT OF THE INTERIOR}

BRUCE BABBITT, Secretary

U.S. GEOLOGICAL SURVEY

Charles G. Groat, Director

Any use of trade, product, or firm names is for descriptive purposes only and does not imply endorsement by the U.S. Geological Survey.

For additional information write to:

District Chief

U.S. Geological Survey

1201 Pacific Avenue, Suite 600

Tacoma, Washington 98402
Copies of this report may be purchased from:

U.S. Geological Survey

Branch of Information Services

Box 25286

Denver, Colorado 80225 


\section{CONTENTS}

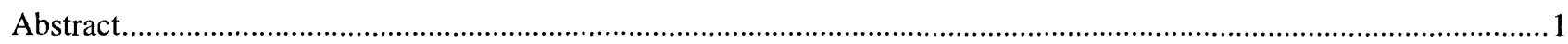

Introduction

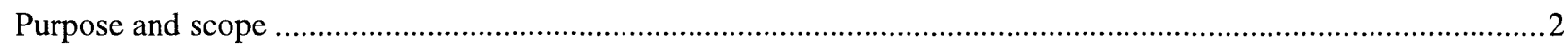

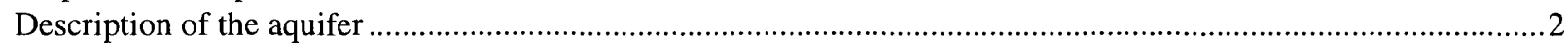

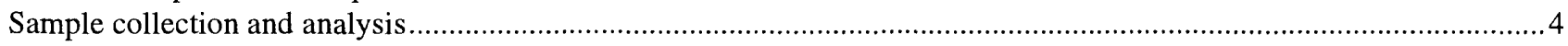

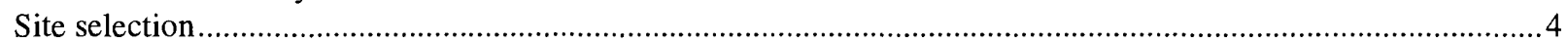

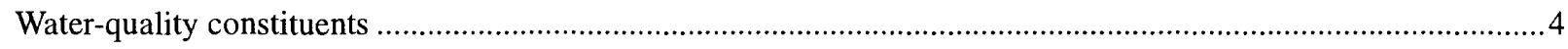

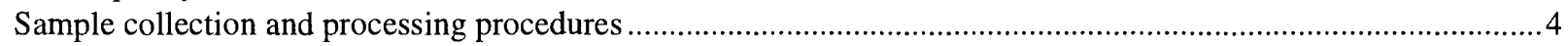

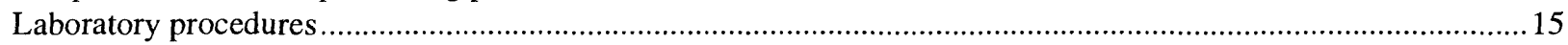

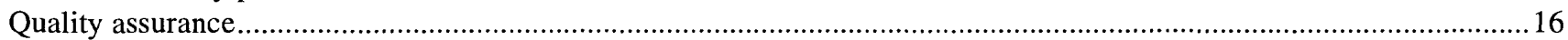

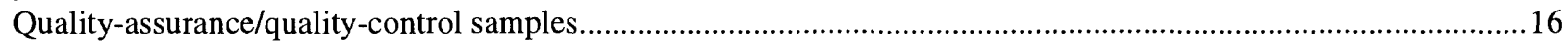

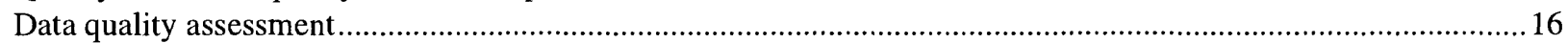

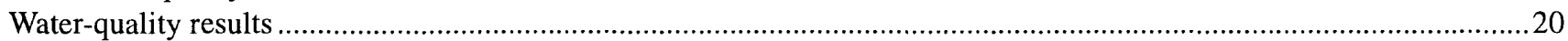

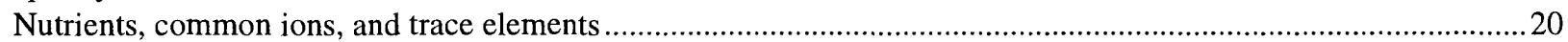



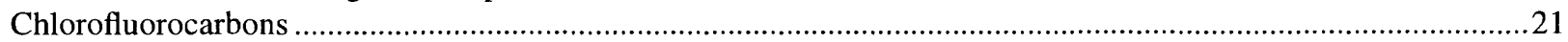

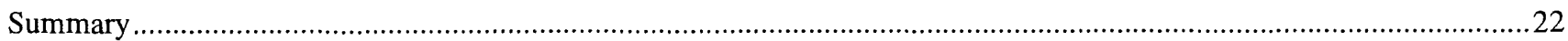

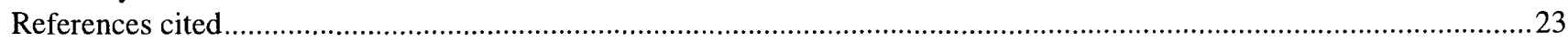

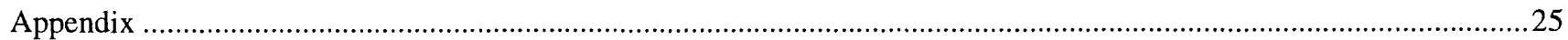

\section{FIGURE}

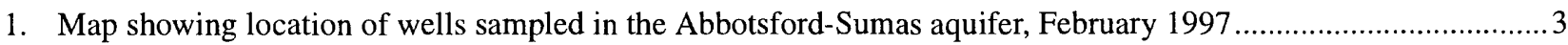

\section{TABLES}

1. Water-level and well construction information of sampled wells ..............................................................5

2. Field measurements, common ions, nutrients, and trace elements measured in filtered groundwater samples collected from wells in the Abbotsford-Sumas aquifer, February 1997 .....................................6

3. Volatile organic compounds analyzed in ground water from the Abbotsford-Sumas aquifer, February 1997, and minimum reporting levels, drinking water standards, and freshwater criteria for protection of aquatic life.

4. Pesticide compounds analyzed in ground water from the Abbotsford-Sumas aquifer,

February 1997, and minimum reporting levels, drinking water standards, and freshwater criteria for protection of aquatic life

5. Volatile organic compounds and pesticides detected in samples of shallow ground water from the transboundary region of the Abbotsford-Sumas aquifer, February 1997

6. Field measurements and concentrations of inorganic constituents in transboundary ground water from the Abbotsford-Sumas aquifer.

7. Concentration of chlorofluorocarbons in ground-water samples and calculated equalibrium vapor phase concentration 
CONVERSION FACTORS AND VERTICAL DATUM

\begin{tabular}{rll}
\hline Multiply & By & To obtain \\
\hline centimeter $(\mathrm{cm})$ & 0.3937 & inch \\
meter $(\mathrm{m})$ & 3.281 & foot \\
kilometer $(\mathrm{km})$ & 0.6214 & mile \\
square kilometer $(\mathrm{km} 2)$ & 0.3861 & square mile \\
liter $(\mathrm{L})$ & 0.2642 & gallon \\
\hline
\end{tabular}

Temperature: To convert temperature given in this report in degrees Celsius $\left({ }^{\circ} \mathrm{C}\right)$ to degrees Fahrenheit $\left({ }^{\circ} \mathrm{F}\right)$, use the following equation: ${ }^{\circ} \mathrm{F}=9 / 5^{\circ} \mathrm{C}+32$.

Sea Level: In this report "sea level" refers to the National Geodetic Vertical Datum of 1929 (NGVD of 1929)--a geodetic datum derived from a general adjustment of the first-order level nets of both the United States and Canada, formerly called Sea Level Datum of 1929.

Elevation: In this report, "elevation" is measured in meters above sea level. 


\title{
Ground-Water Quality Data from the Abbotsford- Sumas Aquifer of Southwestern British Columbia and Northwestern Washington State, February 1997
}

\author{
By Stephen E. Cox and Hugh Liebscher
}

\section{ABSTRACT}

Ground-water quality and hydrogeologic data were collected from nine wells in the Abbotsford-Sumas aquifer near the international boundary separating Canada and the United States. The samples were collected to provide detailed information on the concentrations of chemical constituents in ground water moving from Canada to the United States. Samples were analyzed for a selection of common ions, nutrients, trace elements, pesticides, and volatile organic compounds including three chlorofluorocarbons used to estimate residence times of ground water. The concentrations of nitrate were greater than 10 milligrams per liter in seven of nine wells exceeding criteria for both Canadian and United States drinking water guidelines and standards, respectively. The concentrations of common ions, trace elements, and other nutrients were generally small.

Twenty-three pesticides and volatile organic compounds were detected in the ground water.

The concentrations of these organic compounds ranged from 0.01 to 23 micrograms per liter, which were below drinking water guidelines or standards. Three chlorofluorocarbons were detected in these ground-water samples. Concentrations of chlorofluorocarbons were generally much greater than would be useful to provide reliable estimates of ground-water residence time.

\section{RÉSUMÉ}

Des données concernant la qualité des eaux souterraines et des données hydrogéologiques ont été recueillies à partir d'échantillons prélevés dans neufs puits plongeant dans la nappe aquifère d'Abbotsford-Sumas, près de la frontière canadoaméricaine. Les échantillons ont été prélevés pour déterminer avec précision la concentration des produits chimiques contenus dans les eaux souterraines qui passent du Canada aux États-Unis. On a mesuré dans ces échantillons un certain nombre d'ions communs, de nutriants, d'oligo-éléments, de pesticides et de composés organiques volatiles, dont trois chlorofluorocarbones utilisés pour estimer le temps de séjour de l'eau souterraine.

La concentration de nitrates s'est avérée supérieure à 10 milligrammes par litre dans sept des neuf puits, ce qui dépasse les directives canadiennes et les normes américaines en matière d'eau potable. La concentration des ions communs, des oligo-éléments et des autres nutriants était en générale faible. Vingt-trois pesticides et composés organiques volatiles ont d'autre part été détectés dans les échantillons. La concentration de ces composés organiques variait entre 0,01 et 23 microgrammes par litre, au-dessous de la limite imposée par les directives et les normes en matière d'eau potable. Trois chlorofluorocarbones ont été détectés mais leur concentration était en général trop grande pour que l'on puisse les utiliser pour estimer de façon fiable le temps de séjour de l'eau souterraine. 


\section{INTRODUCTION}

The Abbotsford-Sumas aquifer is bisected by the international boundary between the Province of British Columbia, Canada, and the State of Washington, United States of America (fig. 1). In this area, the Abbotsford-Sumas aquifer is the most extensively used aquifer on both sides of the international boundary. It supplies water for domestic, municipal, agricultural, and industrial purposes for residents of both countries. Residents of Abbotsford and Sumas, as well as most rural residents in the area, obtain their water from this aquifer. During peak water demands, the aquifer currently supplies water to over 115,000 people. In addition, the aquifer provides the majority of baseflow to several fish rearing tributaries of the Nooksack, Sumas, and Fraser Rivers.

Land use over most of the aquifer is largely agricultural. Poultry and raspberry production are the predominant agricultural activities over the Canadian side of the aquifer while dairy and raspberry production are the major activities over the United States side of the aquifer. Other agricultural activities include corn, potato, and swine production. Urban development and light industry are centered around the Cities of Abbotsford, Lynden, and Sumas. Rural residential housing is increasing throughout the area.

The quality of ground water in the AbbotsfordSumas aquifer is a concern to residents and government agencies of both Canada and the United States. Previous investigations have identified nitrate contamination and the presence of selected pesticides in ground water of the Abbotsford-Sumas aquifer at a number of locations on both sides of the international boundary (Liebscher and others, 1992; Erickson and Norton, 1990; Cox and Kahle, 1999). Information was lacking on the occurrence and concentrations of a broad spectrum of other organic compounds and waterquality constituents in ground water flowing across the boundary.

\section{Purpose and Scope}

The objective of this investigation was to determine if selected organic compounds and trace elements were present in a single set of ground-water samples collected from the transboundary area of the Abbotsford-Sumas aquifer. This report presents data from 10 samples of ground water collected from 9 water-table wells located near the boundary between Canada and the United States from February 3 to February 7, 1997. The data were collected jointly by the U.S. Geological Survey (USGS) and Environment Canada (EC), utilizing sampling and analytical techniques developed by the USGS to accurately measure low concentrations of organic compounds and trace elements in ground water.

\section{Description of the Aquifer}

The Abbotsford-Sumas aquifer is a surficial aquifer, located from the City of Abbotsford, British Columbia, to Lynden, Washington (fig. 1). The Abbotsford-Sumas aquifer is part of a larger surficial aquifer that extends throughout much of the Nooksack and Fraser River Lowland. The aerial extent of the Abbotsford-Sumas aquifer is approximately 161 square kilometers (62 square miles) and is roughly bisected by the Canadian-United States boundary. Ground water generally flows southerly, moving across the international boundary from Canada to the United States (Liebscher and others, 1992; Cox and Kahle, 1999). Recharge to the aquifer is primarily from direct precipitation, which occurs predominantly from October to May. Mean annual precipitation varies from about 100 centimeters ( 40 inches) near Lynden to 165 centimeters (65 inches) near Abbotsford. Discharge from the aquifer is by pumping and seepage to streams, most notably Fishtrap Creek and the Nooksack River (fig. 1).

The Abbotsford-Sumas aquifer is made up predominantly of uncompacted sands and gravels of a glacial outwash plain that are permeable and allow rapid infiltration. Lenses of fine-grain sediments are commonly found throughout the aquifer resulting in complex ground-water flow paths. The aquifer is underlain by an extensive fine-grain glaciomarine deposit that is referred to in Canada as the Fort Langley clays, (Halstead, 1986) and in the United States as the Everson Glacio-Marine Drift (Easterbrook, 1976). The aquifer is typically unconfined and ranges from 0 to 65 meters ( 0 to 213 feet) thick. The aquifer is thickest in the northeastern part of the aquifer where glacial terminal moraine deposits are incorporated within the outwash deposits thickening the aquifer and resulting in semiconfined conditions at some locations. The water table is generally from 3 to 25 meters below land surface in the transboundary area. 


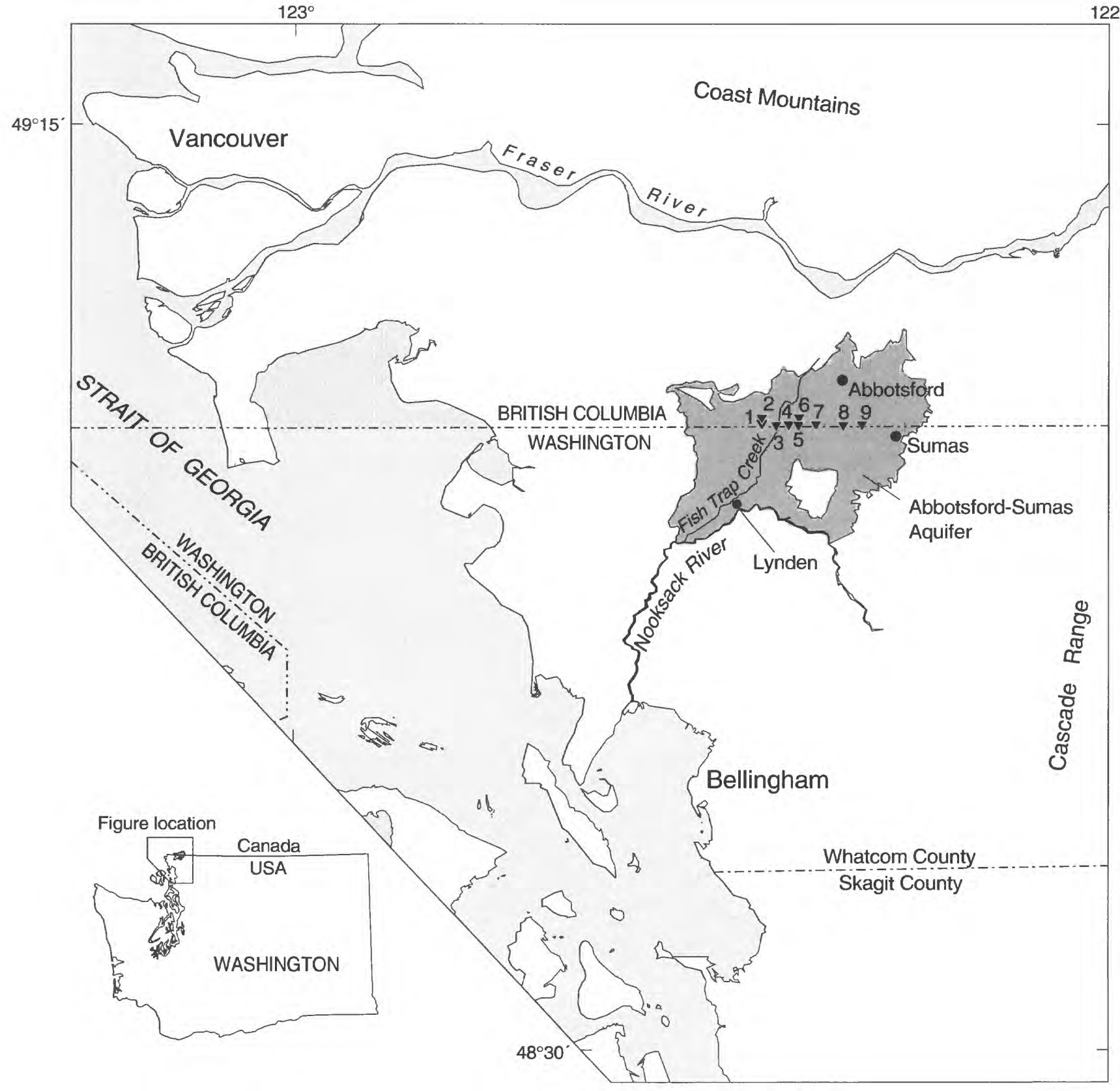

\section{EXPLANATION}

$\nabla^{2}$ Well sampled for ground-water quality

$\begin{array}{clc}\begin{array}{c}\text { Map } \\ \text { Number }\end{array} & \begin{array}{c}\text { Well } \\ \text { Name }\end{array} & \begin{array}{c}\text { National Water Information } \\ \text { System Site Identifier }\end{array} \\ 1 & 91-13 & 490023122252902 \\ 2 & 91-15 & 490023122252901 \\ 3 & \text { FTC-1-24 } & 490009122243102 \\ 4 & \text { ABB5 } & 490020122213201 \\ 5 & 94-\text { LEH } & 490010122252901 \\ 6 & \text { BCME-B-20 } & 490031122225301 \\ 7 & \text { ABB2 } & 490020122213201 \\ 8 & \text { ABB4 } & 490011122193201 \\ 9 & 94-S R-29 & 490011122181001\end{array}$

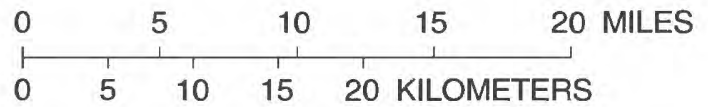

Figure 1. Location of wells sampled in the Abbotsford-Sumas aquifer, February, 1997. 


\section{Site Selection}

Ground-water samples were collected from nine existing monitoring wells screened in the AbbotsfordSumas aquifer and located in Canada within 400 meters of the international boundary (fig. 1). The criteria for selection of wells for sampling included: (1) wells located along and close to the international boundary; and (2) existing water-table wells completed in the Abbotsford-Sumas aquifer. Six wells were within 50 meters north of the international boundary. The other wells, BCME-B-20, 91-13, and 91-15, were located about 400 meters north of the boundary. Wells with shallow depth to water were selected, because the potential for contamination was thought to be greatest near the water table. Well 94-SR-29, which is screened about 16 meters below the water table, was also selected because ground water from the area near this well flows toward water-supply wells used by the City of Sumas, Wash. (Associated Earth Sciences Inc., 1996).

All wells were constructed of PVC plastic pipe, 5.1 centimeters ( 2 inches) in diameter. The length of the well screen for four of the observation wells was 1.51 meters ( 5 feet); four other wells had screens that were 1 meter ( 3.3 feet) in length. The remaining well, 94-LEH, was screened from a depth of 4.6 to 21.3 meters (15 to 70 feet). However, prior to sampling, a temporary 0.5 -meter ( 1.6 feet) cellulose packer was installed from 5.5 to 6 meters below land surface so that only the upper 1 meter of the well screen was open to the aquifer while water was being pumped from the well. Generally, the static water level in wells was near the screened interval. Well-construction and waterlevel data collected prior to sampling are listed in table 1. Drillers' descriptions of lithology encountered while drilling the wells are included in the appendix.

\section{Water-Quality Constituents}

The ground-water samples were collected during the winter season because seasonal variations in ground-water nitrate concentrations in the AbbotsfordSumas aquifer have been observed to be larger during the winter (Dasika, 1996). It is likely that other waterquality constituents related to land-use activities would also be largest in the winter.
Ground-water samples from all wells were analyzed in the field at the time of sampling to determine the concentration of dissolved oxygen, $\mathrm{pH}$, specific conductance, and alkalinity of a filtered water sample. Samples collected in polyethylene or glass bottles were sent to the National Water Quality Laboratory (NWQL), in Arvada, Colo., for laboratory analysis of common ions, nutrients, dissolved organic carbon, trace elements, volatile organic compounds (VOCs), and pesticides. A listing of constituents and minimum reporting levels (MRLs) is presented in table 2 for field parameters, common ions, nutrients, and trace elements. An alphabetical listing of the VOCs and pesticides that were analyzed, their chemical names, common names, Chemical Abstract Services registry numbers, MRLs, and drinking water standards or guidelines from the U.S. Environmental Protection Agency and Health Canada is presented in tables 3 and 4. Water-quality data from these analyses are stored in the USGS National Water Information System (NWIS). Site identifiers used to locate information in NWIS are shown in figure 1.

Additional samples from seven wells were sent to the USGS Chlorofluorocarbon Laboratory in Reston, Virg., for determination of the concentrations of three chlorofluorocarbon (CFC) compounds: trichlorofluoromethane, CFC-11; dichlorodifluoromethane, CFC-12; and 1,1,2-trichloro-1,2,2-trifluoroethane, $\mathrm{CFC}-113$. In some instances concentrations of these compounds have been shown to be useful in determining when ground water was recharged and thereby provide an estimate of the ground-water residence times (Busenberg and Plummer, 1992).

\section{Sample Collection and Processing Procedures}

Sample collection procedures followed the protocols and guidelines established for the USGS National Water Quality Assessment (NAWQA) program to minimize sample contamination (Koterba and others, 1995). All sampling equipment used was dedicated to sampling ground water with low concentrations of organic and inorganic constituents. Equipment that came in contact with the samples during collection procedures, including the submersible pump, fittings, and water lines, were composed of either 316 Stainless Steel, Teflon ${ }^{\circledR}$ or copper. Copper tubing was used only in the collection of CFC samples where refrigeration-grade copper tubing was used 


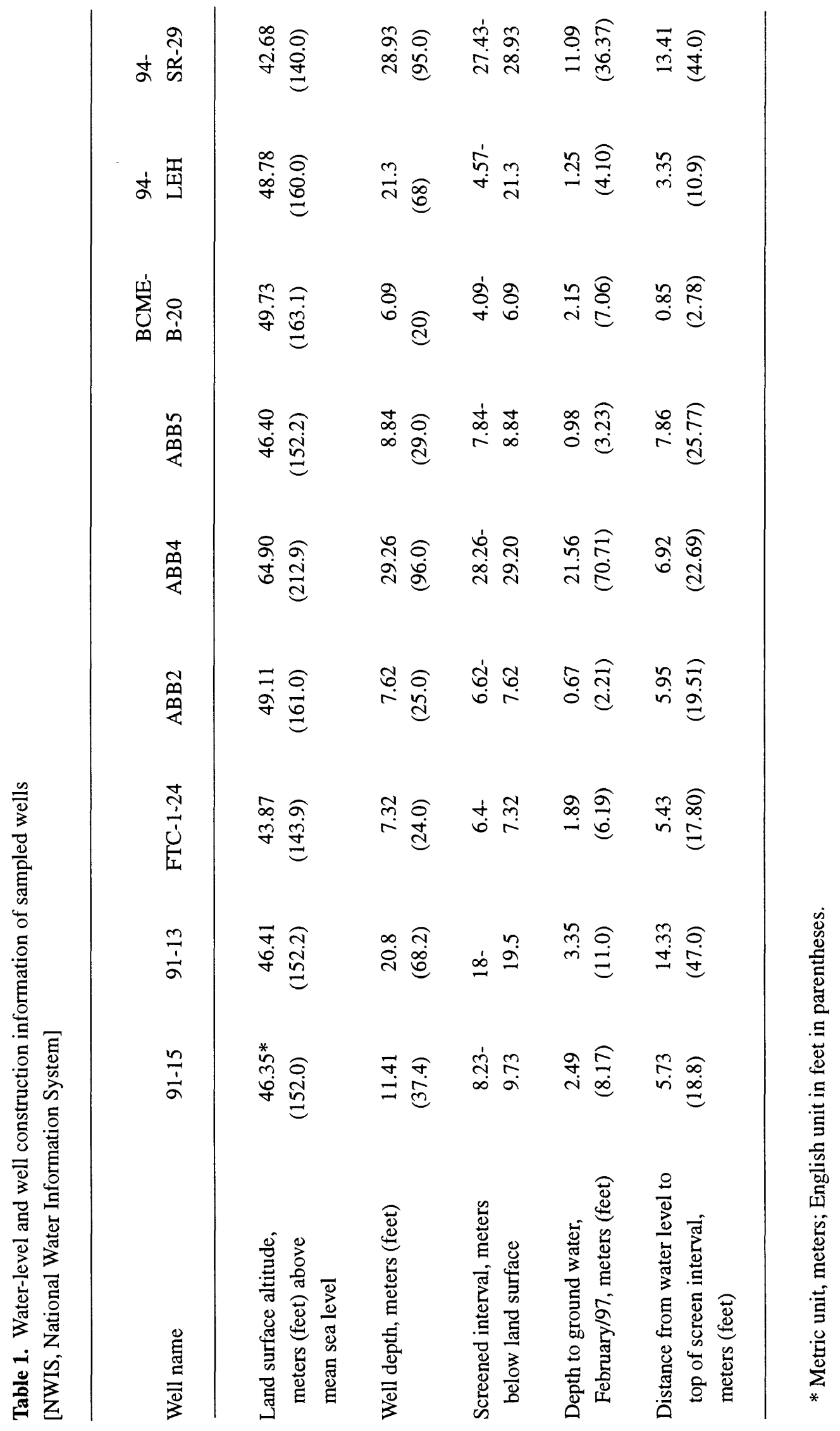


Table 2. Field measurements, common ions, nutrients, and trace elements measured in filtered ground-water samples collected from wells in the Abbotsford-Sumas aquifer, February 1997

[mg/L, milligrams per liter; $\mu \mathrm{g} / \mathrm{L}$, micrograms per liter. The filter size was $0.45 \mu \mathrm{m}$ (micrometer, or micron). Ammonia, nitrate, and nitrite are reported as nitrogen, and orthophosphate is reported as phosphorus]

\section{FIELD MEASUREMENTS ${ }^{1}$}

Constituent or

physical property

Temperature

Specific Conductance

Alkalinity

\begin{abstract}
Reporting
units
\end{abstract}

Degrees C

$\mu \mathrm{s} / \mathrm{cm}$

$\mathrm{mg} / \mathrm{L}$ as $\mathrm{CaCO}_{3}$
Constituent or physical property

$\mathrm{pH}$

Dissolved oxygen
Reporting

units

Standard unit

$\mathrm{mg} / \mathrm{L}$

\section{COMMON IONS AND NUTRIENTS}

Constituent of

physical property

\section{Minimum}

Reporting

level (mg/L)
Constituent or physical property
Minimum

Reporting level (mg/L)

\begin{tabular}{lc}
\hline Calcium & 0.02 \\
Magnesium & 0.01 \\
Sodium & 0.2 \\
Potassium & 0.1 \\
Chloride & 0.1 \\
Sulfate & 0.1 \\
Fluoride & 0.1 \\
Silica, as $\mathrm{SiO}_{2}$ & 0.01 \\
Bicarbonate, as $\mathrm{HCO}_{3}$ & 0.01 \\
Ion balance & (percent)
\end{tabular}

$\begin{array}{ll}\text { Nitrate plus nitrite, as N } & 0.05 \\ \text { Nitrite, as N } & 0.01 \\ \text { Ammonia, as N } & 0.015 \\ \text { Ammonia plus } & \\ \quad \text { organic nitrogen } & 0.02 \\ \text { Orthophosphate, as P } & 0.01 \\ \text { Phosphorus } & 0.01 \\ \text { Carbon, organic, total as C } & 0.01 \\ \text { Residue on evaporation } & 1 \\ \text { Sum of dissolved constituents } & 1\end{array}$

TRACE ELEMENTS

\begin{tabular}{llllll} 
Element & $\begin{array}{l}\text { Minimum } \\
\text { Reporting } \\
\text { level }(\mu \mathrm{g} / \mathrm{L})\end{array}$ & Element & $\begin{array}{l}\text { Minimum } \\
\text { Reporting } \\
\text { level }(\mu \mathrm{g} / \mathrm{L})\end{array}$ & Element & $\begin{array}{l}\text { Minimum } \\
\text { Reporting } \\
\text { level }(\mu \mathrm{g} / \mathrm{L})\end{array}$ \\
\hline Antimony & 1 & Chromium & 1 & Molybdenum & 1 \\
Aluminum & 1 & Cobalt & 1 & Nickel & 1 \\
Arsenic & 1 & Copper & 1 & Selenium & 1 \\
Barium & 1 & Iron & 3 & Silver & 1 \\
Beryllium & 1 & Lead & 1 & Uranium & 1 \\
Bromide & 1 & Manganese & 1 & Zinc & 1 \\
Cadmium & 1 & Mercury & 0.1 & & \\
\hline
\end{tabular}

\footnotetext{
${ }^{1}$ Field parameters other than alkalinity, measured in unfiltered sample water.

${ }^{2}$ Ion balance is the (sum of the cations minus the sum of anion) / total sum of cations and anions; expressed as percent.
} 


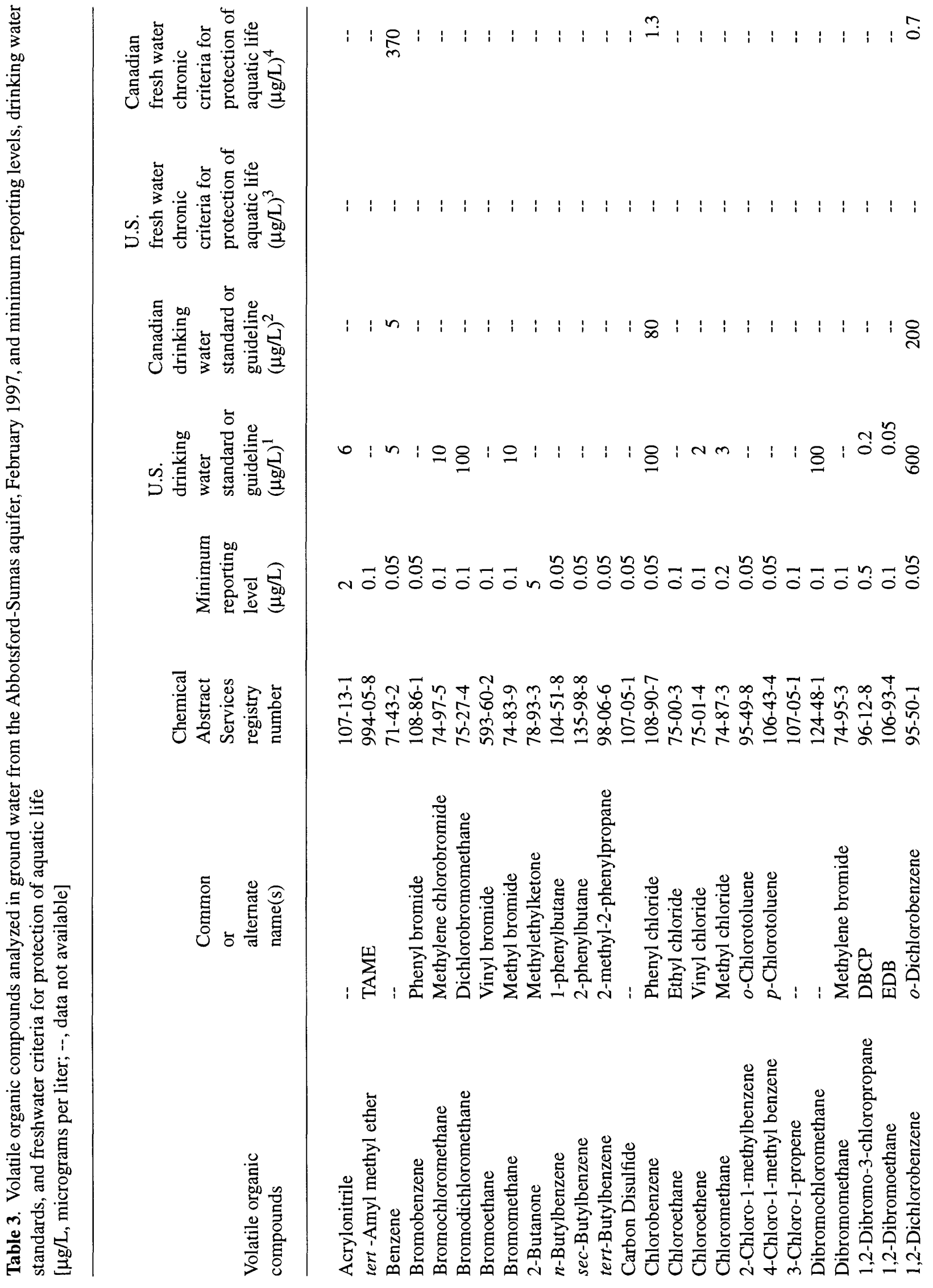




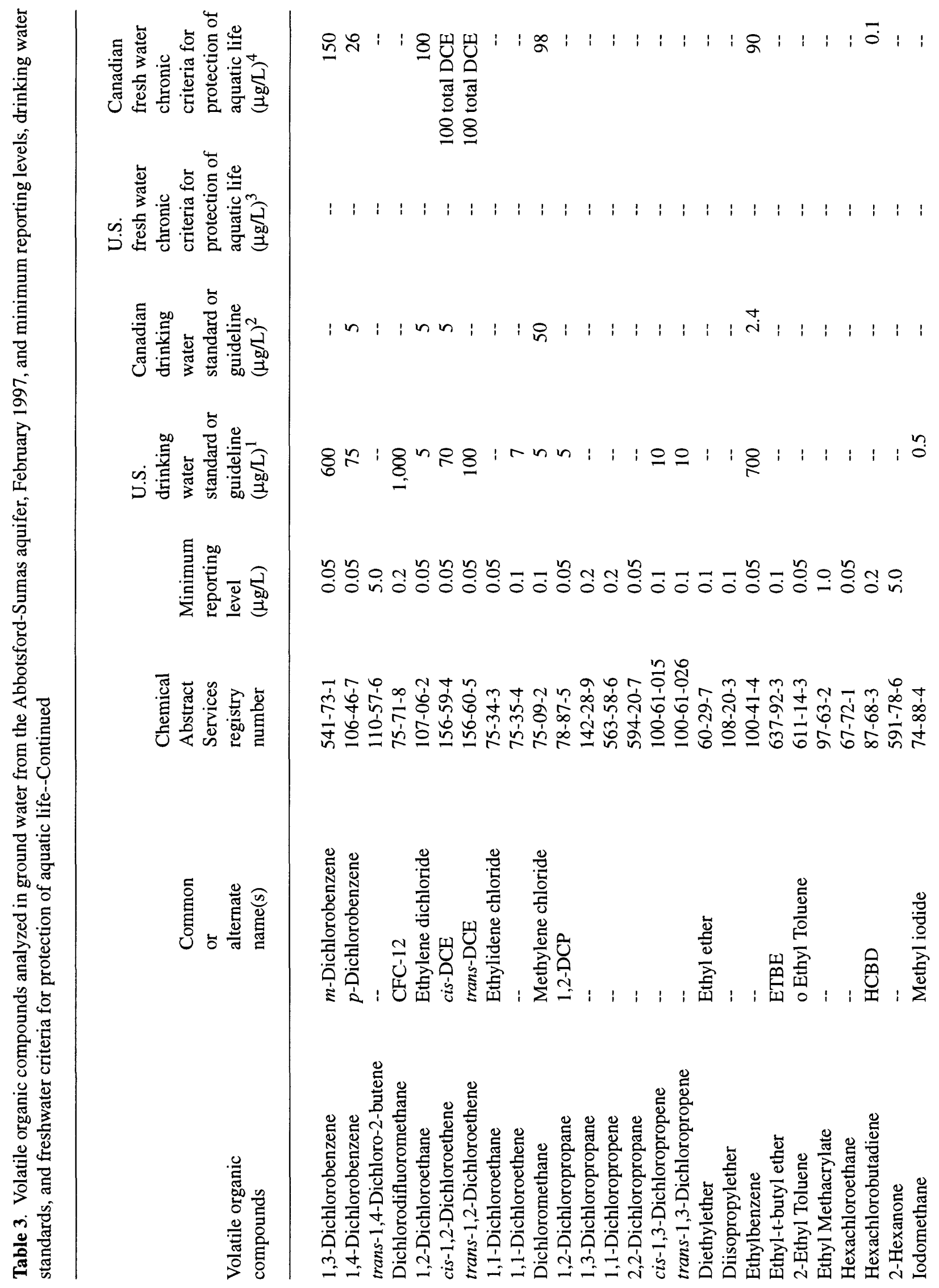




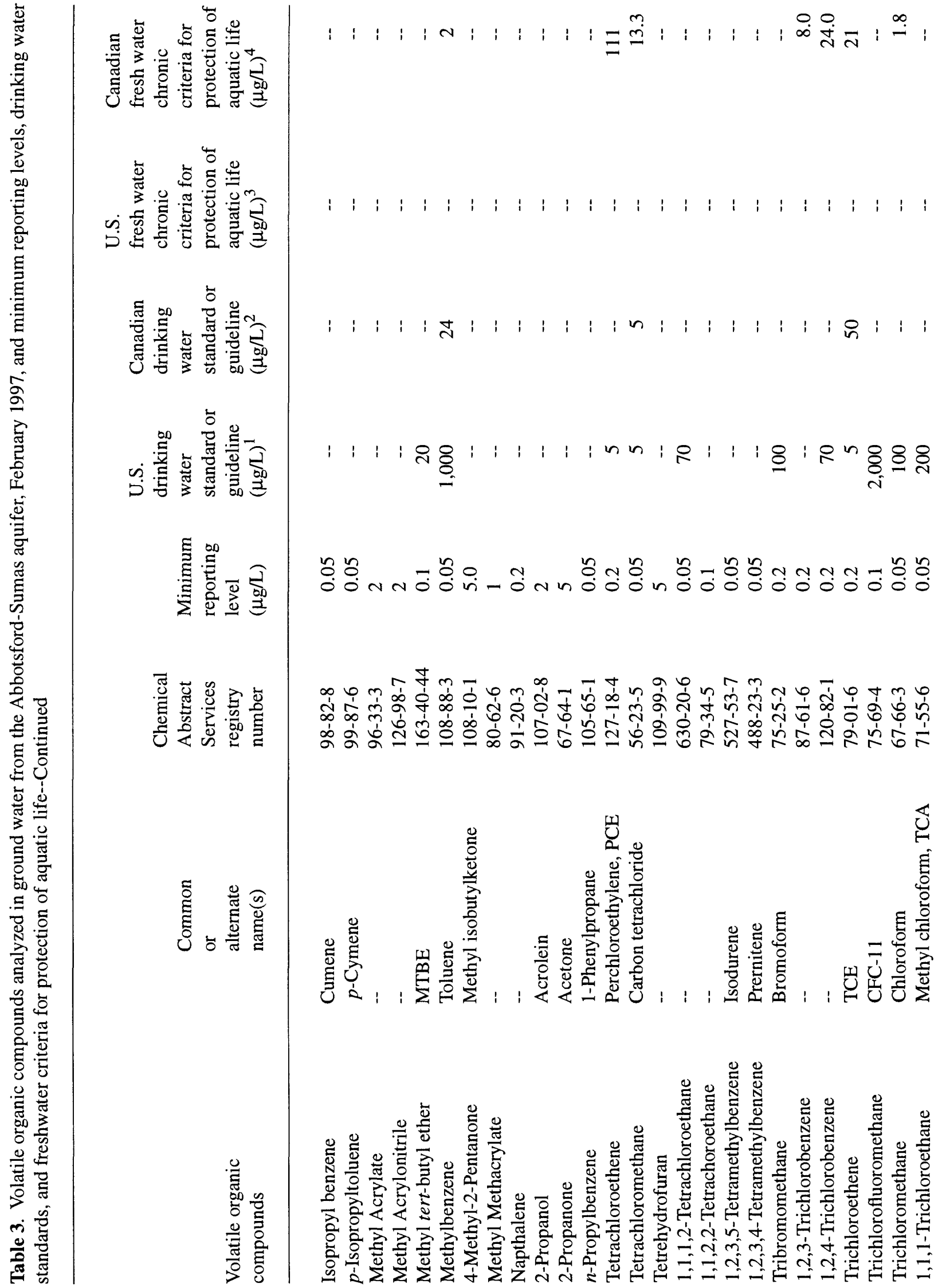




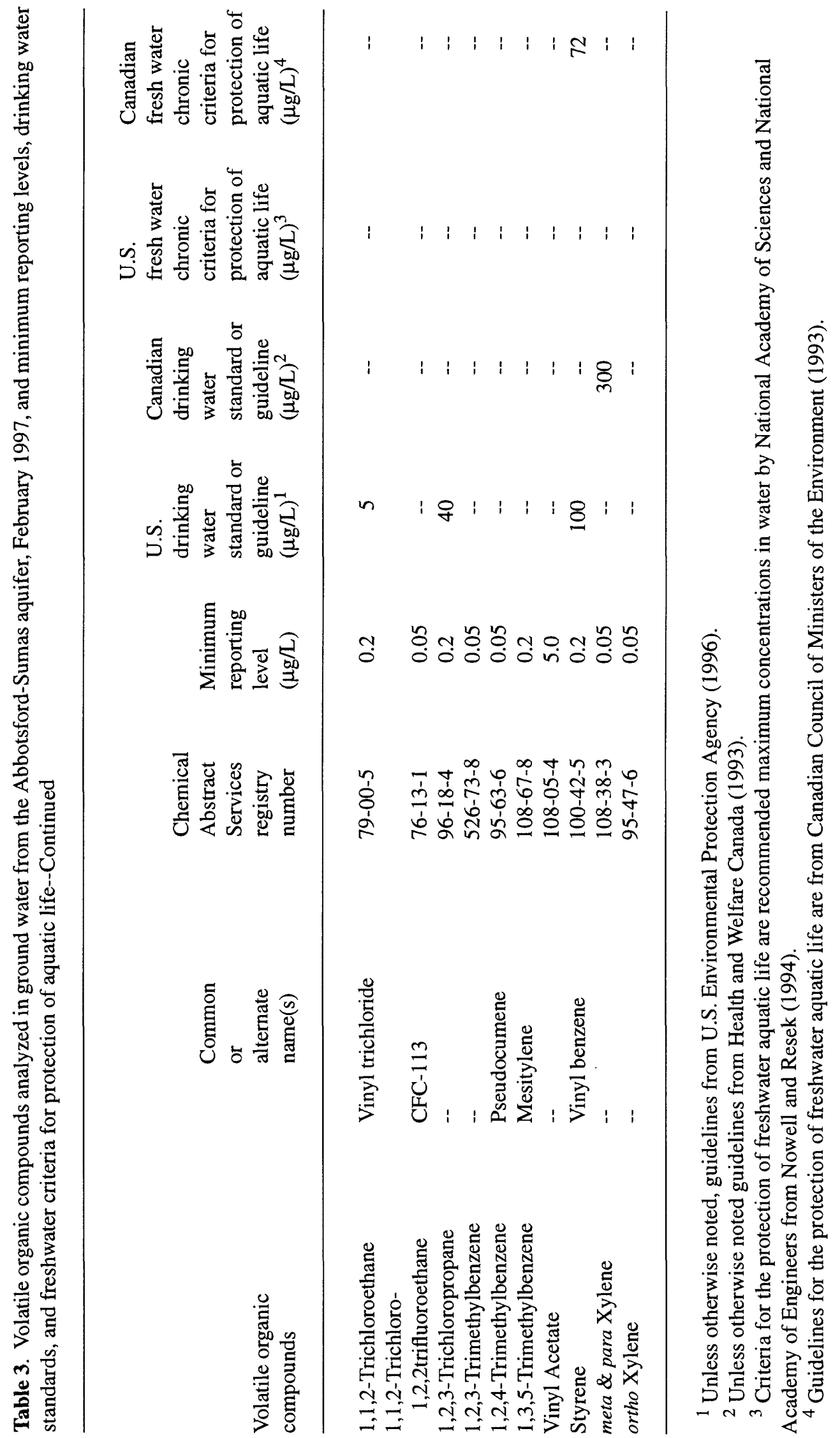




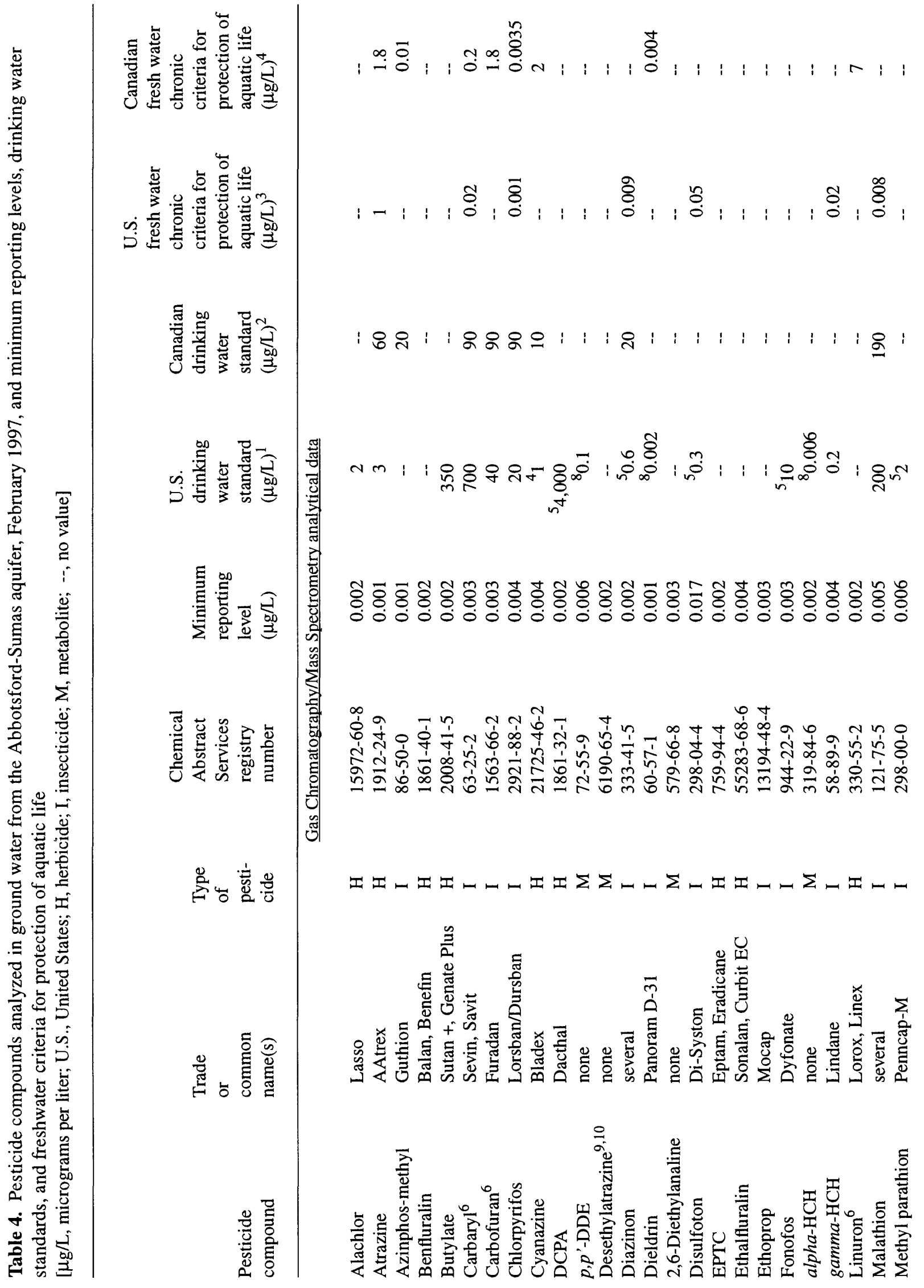




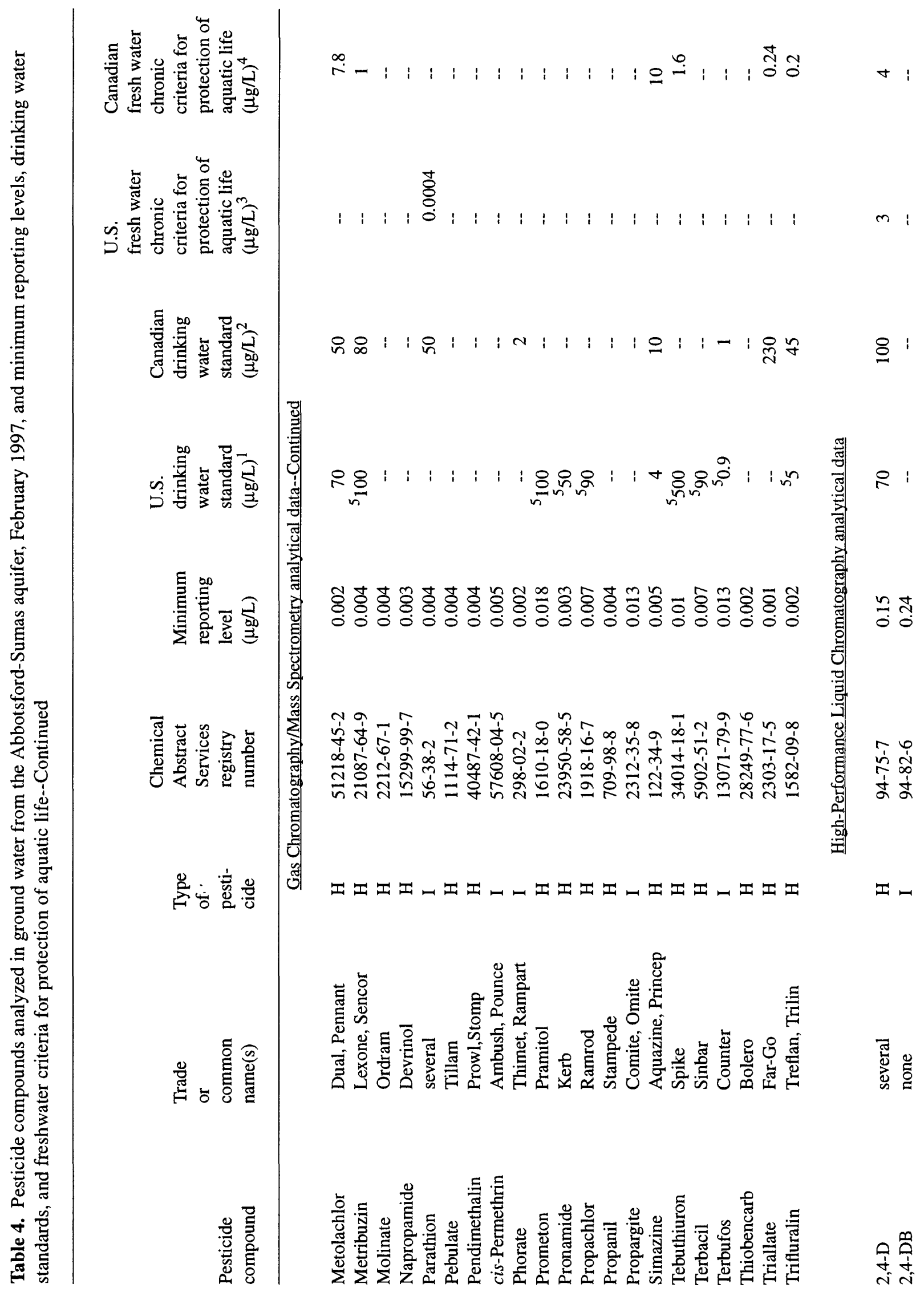




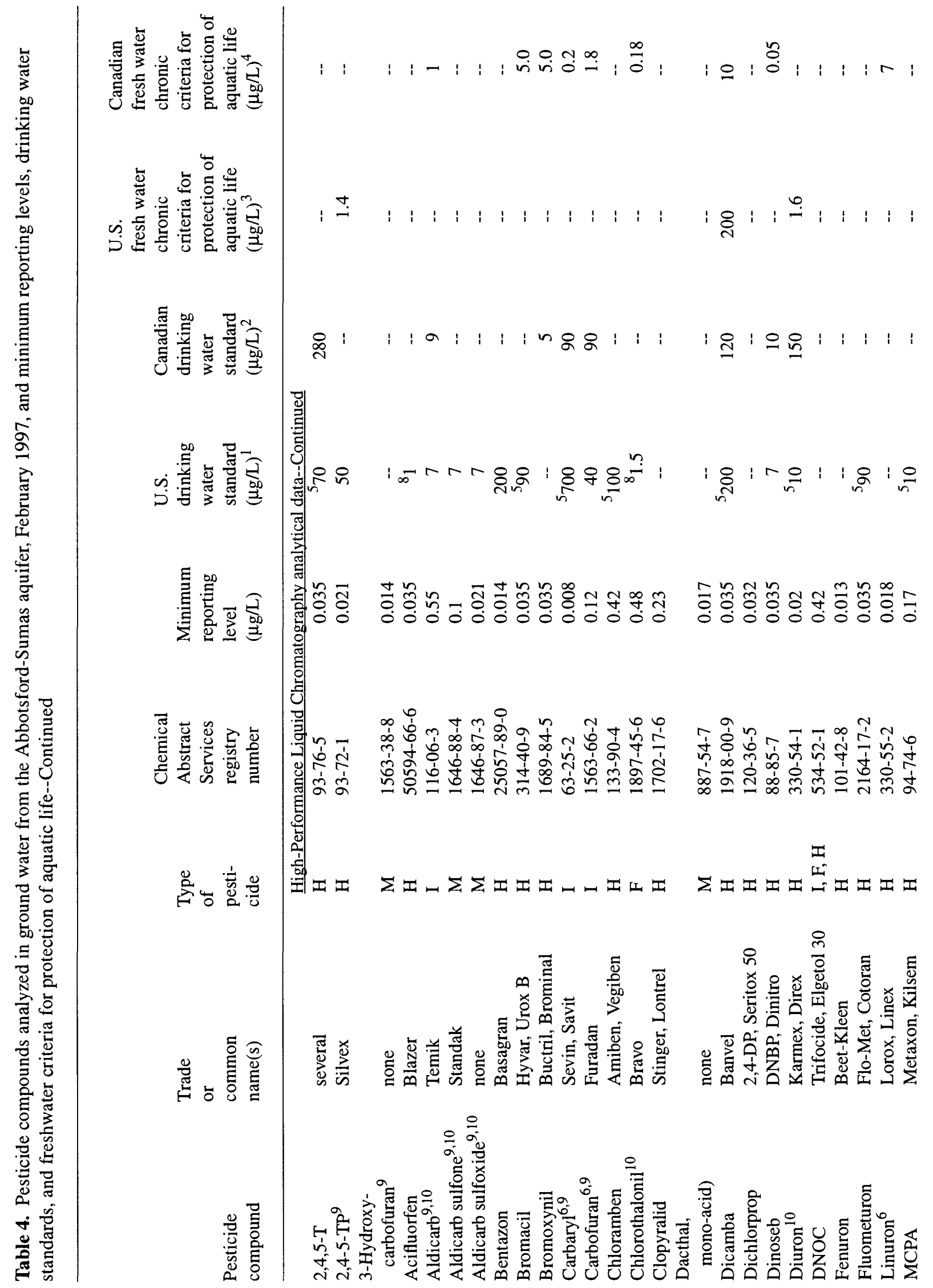




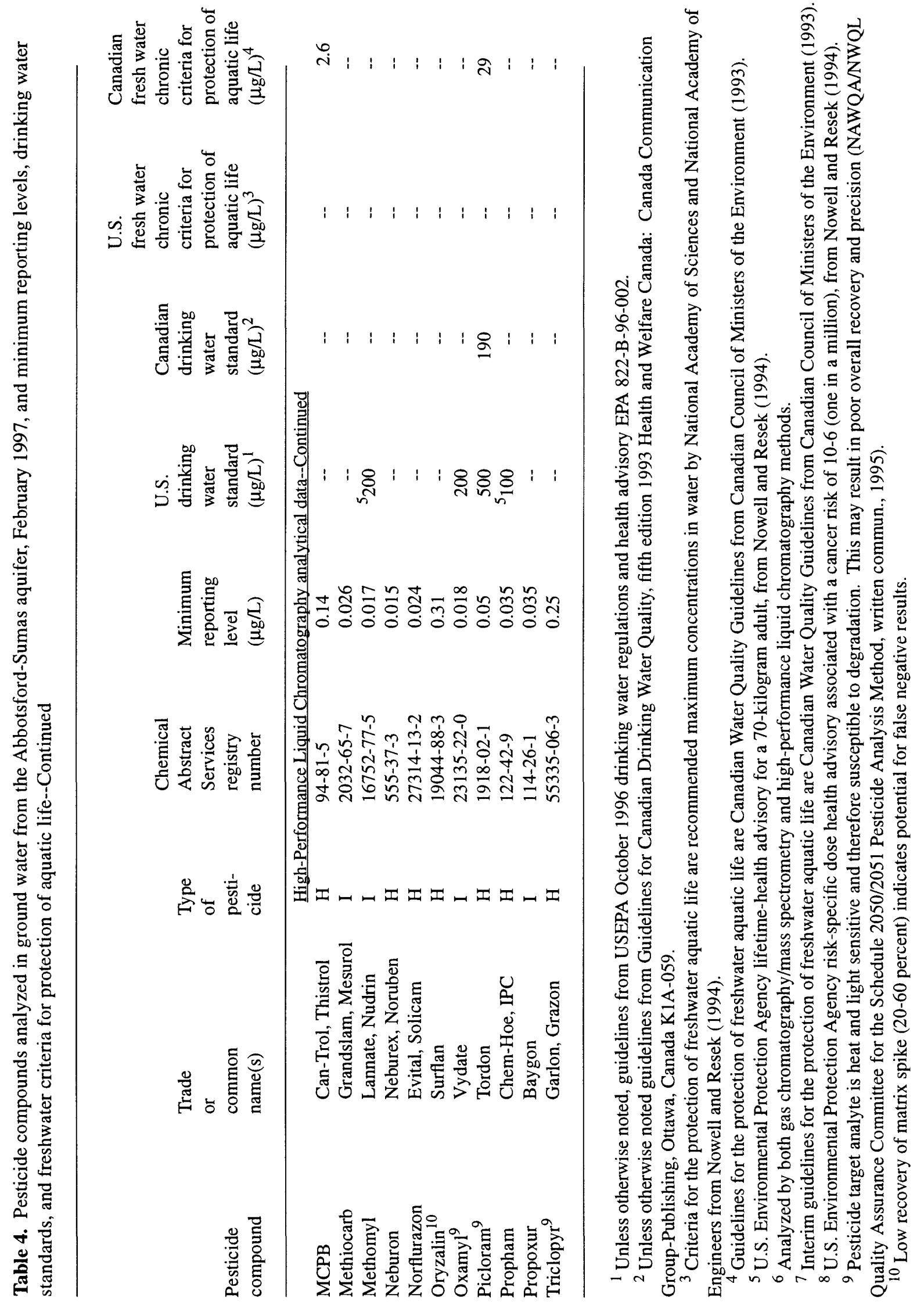


between the submersible pump and the sampling apparatus. All field supplies, bottles, reagents, and surrogates that were used for sample collection were tested for contamination and approved by either the manufacturer or the USGS National Water Quality Laboratory.

Field instruments were calibrated at the beginning of each day and between every second sampling site. At each site, water levels and down-hole water temperature were measured before installation of submersible-pump sampling equipment. The sampling pump was positioned at or just above the well's screened interval and water was pumped at a rate of about 4 to 8 liters per minute. Each well was initially pumped to remove at least three casing volumes after which field parameters were monitored until stable readings of $\mathrm{pH}$, specific conductance, temperature, and dissolved oxygen were obtained. These parameters were measured in a flow-through chamber so that ground water was not exposed to the atmosphere prior to monitoring. Stable readings were defined as variations about a central value of less than or equal to $0.1 \mathrm{pH}$ units, $0.2^{\circ} \mathrm{C}$ (degrees Celsius) for temperature, plus or minus 3 percent for specific conductance, and $0.3 \mathrm{mg} / \mathrm{L}$ (milligram per liter) for dissolved oxygen between successive readings 3 minutes apart.

Dissolved oxygen readings of less than $1 \mathrm{mg} / \mathrm{L}$ were confirmed using a Chemetrix rhodazine dye method (White and others, 1990). Field alkalinity of a filtered sample was determined at each site by incremental titrations.

Unfiltered water samples were collected for analysis of volatile organic compounds in 40-milliliter septum vials, which were filled slowly to avoid aeration and then preserved with one to three drops of hydrochloric acid to achieve a pH of from 1.7 to 2.0. Pesticide samples were filtered through a 0.7 -micrometer glass fiber filter and field-extracted from the filtrate by pumping through solid-phase extraction cartridges as described by Shelton (1994) and Sandstrom and others (1992). Samples for analysis of trace elements, common ions, and nutrients were filtered using a 0.45 -micrometer cellulose filter. Trace elements and cation samples were preserved with nitric acid to a $\mathrm{pH}$ of less than 2; samples for analysis of mercury were preserved with 10 milliliters of potassium dichromate. Samples for VOC, pesticide, nutrient, and organic carbon analysis were chilled to 4 degrees Celsius or less and shipped to the laboratory by overnight courier.
All samples received by the laboratory were analyzed within accepted holding times.

Following the collection of these samples, the submersible pump equipped with teflon discharge lines was decontaminated using 0.1 percent solution of Liquinox soap and deionized water following the general procedures described by Koterba and others (1995), however, the methanol rinse was omitted to minimize the potential for contamination of dissolved organic carbon samples. A second submersible pump with a discharge line made of refrigeration-grade copper tubing suitable for collecting CFC samples was installed in the well for collection of CFC samples. CFC samples were collected in triplicate using methods described by Busenberg and Plummer (1992).

\section{Laboratory Procedures}

Concentrations of common ions and trace elements were analyzed by inductively coupled plasma (ICP), with the exception of lead (analyzed by graphite furnace atomic absorption), mercury (analyzed by cold vapor atomic absorption), and chloride and sulfate (analyzed by ion-exchange chromatography). Minimum reporting levels and compounds quantified by these methods are listed in table 2. The analytical methods used are described further by Fishman (1993).

Concentrations of VOCs were determined by purge and trap gas chromatography with electron impact mass spectrometry (GC/MS) following U.S. Environmental Protection Agency (EPA) Method 524.2 (Rose and Schroeder, 1995; Connor and others, 1998). Minimum reporting levels and compounds quantified by this method are listed in table 3 along with corresponding United States and Canadian drinking water and freshwater guidelines (U.S. Environmental Protection Agency, 1996; Health and Welfare Canada, 1993; and Canadian Council of Ministers of the Environment, 1993). Pesticides were analyzed utilizing solid-phase extraction techniques and gas chromatography and mass spectrometry (GC/MS) analysis with selected ion monitoring as described by Werner and Johnson (1994), Zaugg and others (1995) and Werner and others (1996). Minimum reporting levels and compounds quantified by this method are listed in table 4 . CFCs were analyzed by gas chromatography following procedures described by Busenberg and Plummer (1992). 


\section{QUALITY ASSURANCE}

Procedures were followed to insure the collection of data with known and acceptable quality. These procedures included the use of non-contaminating sample collection techniques described in the previous section, the collection of quality assurance and control (QA/QC) samples, and review of laboratory data by laboratory and project personnel.

\section{Quality-Assurance/Quality-Control Samples}

Quality-control samples included two equipment-blank samples and one replicate sample of organic constituents collected as part of this study, and review of field-matrix spike data collected from a concurrent study. Laboratory QA/QC checks included the analysis of double blind reference materials, daily blanks, daily standards, daily instrument tuning, surrogate spike recovery, and other quality-control check samples as described by Pritt and Raese (1995). Analyte recovery and analytical precision and accuracy are described by Rose and Schroeder (1995), Werner and Johnson (1994), and Werner and others (1996).

Equipment blanks for VOCs were collected immediately before and after the 10 well-water samples were collected. Certified VOC-free water was used to process the equipment blanks. Laboratory grade deionized water was used to wash and decontaminate the equipment and was analyzed for VOCs, trace elements, and common ions prior to conducting field work. The VOC sample vials were precleaned and certified by the manufacturer to be free of VOCs; however, the minimum detection values shown on the certificate of analysis for the VOC sample vials was often larger than the minimum detection level reported for the analytical methods used by the NWQL. Equipment blanks for pesticides were collected immediately before, midway through the sampling, and after the 10 well-water samples were collected. The pesticide equipmentblank sample collected midway through this sampling was analyzed and contained no detectable concentrations of pesticides, as did the previous six pesticide equipment-blank samples obtained with this sampling equipment for other studies, thus no other pesticide equipment-blank samples were analyzed.

Short-term variability due to variations in sampling technique, variability in analytical technique, and short-term in-situ aquifer chemical variations were assessed by the repeat sampling of one well (well 91-15) 3 days apart following the initial sample collection. Estimates of the bias and variability in the pesticide and VOC data caused by analyte degradation, the effects of ground-water matrix, and the analytical processes were assessed using data from two spikereplicate sample sets collected from a concurrent study which included the Abbotsford-Sumas aquifer. The spike-replicate sample sets were collected in September and December of 1996 as part of the National Water Quality Assessment (NAWQA) of the Puget Sound region. The sample sets were collected from shallow wells screened in glacial-outwash aquifers; one site located in the Abbotsford-Sumas aquifer and the other from a similar site about 200 kilometers south of the aquifer. In these samples, three replicate environmental samples were collected; known concentrations, typically $0.1 \mu \mathrm{g} / \mathrm{L}$ (microgram per liter) of many of the organic compounds were added to two of the replicate samples.

\section{Data Quality Assessment}

Review of quality-assurance data showed that overall, the majority of the 210 water-quality parameters examined showed little significant bias or variability; however, low concentrations of four VOCs and three trace elements were detected in equipmentblank samples indicating the occurrence of sampling or analytical bias for those constituents. All laboratory results are reported in tables 5,6 , and 7 ; results that may be affected by sampling or analytical bias are flagged with a "V". Field-matrix spike information (data not shown) showed low recoveries for three compounds not detected in the environmental samples and high recovery for one compound that was detected.

Three compounds (1-Napthal, Dichlobenil, and Esfenvalerate) with matrix spike recoveries of less than 20 percent were removed from the analyte list. The concentration of Tebuthiuron, which showed a recovery greater than 140 percent, was flagged with the "V" code to indicate potential bias. Other organic compounds (Aldicarb, Aldicarb sulfone, Aldicarb sulfoxide, Chlorothalonil, Desethylatrazine, Diuron, and Oryzalin) that were not detected in the groundwater samples showed recoveries between 20 and 60 percent. A notation was added to the analyte list (table 4) indicating low recoveries and the potential for falsenegative detections. 
Table 5. Volatile organic compounds and pesticides detected in samples of shallow ground water from the transboundary region of the Abbotsford-Sumas aquifer, February 1997 (Complete analyte lists are in tables 3 and 4) [E, indicates some laboratory quantitative uncertainty and thus the value is flagged as estimated; $V$, indicates potential bias in environmental sample based on quality control data associated with environmental samples. All concentrations in micrograms per liter; $\mu \mathrm{g} / \mathrm{L}$, micrograms per liter; --, constituent not detected]

\begin{tabular}{|c|c|c|c|c|c|c|c|c|c|c|c|c|c|}
\hline \multirow{3}{*}{$\begin{array}{l}\text { Organic } \\
\text { compound } \\
\text { Date in } 1997\end{array}$} & \multirow{3}{*}{$\begin{array}{l}\text { Report- } \\
\text { ing } \\
\text { level } \\
(\mu \mathrm{g} / \mathrm{L})\end{array}$} & \multicolumn{10}{|c|}{ Well name } & \multirow{2}{*}{\multicolumn{2}{|c|}{$\begin{array}{l}\text { Equipment } \\
\text { blanks }\end{array}$}} \\
\hline & & & & & FTC- & & & & BCME- & $94-$ & & & \\
\hline & & $2 / 4$ & $2 / 7$ & $2 / 4$ & $2 / 6$ & $2 / 5$ & $2 / 3$ & $2 / 6$ & $2 / 5$ & $2 / 7$ & $2 / 3$ & $1 / 31$ & $2 / 10$ \\
\hline $\begin{array}{l}\text { Trichlorfluor- } \\
\text { methane }\end{array}$ & 0.1 & 0.20 & 0.19 & E.03 & -- & -- & -- & -- & -- & -- & -- & -- & -- \\
\hline $\begin{array}{l}\text { Carbon di- } \\
\text { sulfide }\end{array}$ & 0.05 & -- & -- & -- & -. & -- & -- & -. & E.005 & E.007 & -- & E.02 & $\cdots$ \\
\hline $\begin{array}{l}\text { 1,1 Dichloro } \\
\text { ethane }\end{array}$ & 0.05 & -- & -- & E.07 & -- & - & - & -- & - & -- & -- & -- & -- \\
\hline $\begin{array}{l}\text { Methyl tert- } \\
\text { butyl ether }\end{array}$ & 0.1 & E.09 & E.09 & - & E0.01 & -- & -- & -- & -- & -- & -- & - & -- \\
\hline Chloroform & 0.05 & E.01 & E.01 & E.02 & - & -- & E. 02 & -- & -- & -- & -- & E. 01 & -- \\
\hline $\begin{array}{l}\text { 1,1,1 Trichloro } \\
\text { ethane }\end{array}$ & 0.05 & E.04 & E.04 & 0.54 & -- & 0.14 & E.009 & -- & $-\cdot$ & -- & -- & -- & -- \\
\hline $\begin{array}{l}\text { Trichloro- } \\
\text { ethylene }\end{array}$ & 0.05 & - & E.005 & -- & -- & -- & -- & -- & -- & -- & -- & -- & -- \\
\hline $\begin{array}{l}\text { 1,2 Dichlor- } \\
\text { propane }\end{array}$ & 0.05 & E.06 & E.07 & 0.11 & E.04 & 0.15 & 0.14 & 0.24 & 0.48 & 0.37 & -- & -- & -- \\
\hline $\begin{array}{l}\text { trans- 1,3 Di- } \\
\text { chloropropene }\end{array}$ & 0.1 & -- & -- & -- & -- & -- & -- & -- & -- & E. 03 & -- & -- & -- \\
\hline $\begin{array}{l}\text { cis- } 1,3 \mathrm{Di}- \\
\text { chloroproene }\end{array}$ & 0.1 & -- & -- & -- & -- & -- & -- & -- & -- & E. 02 & -- & -- & -- \\
\hline $\begin{array}{l}\text { 1,3 Dichloro- } \\
\text { propane }\end{array}$ & 0.05 & -- & -- & -- & -- & -- & -. & -- & E.08 & E. 05 & -- & -- & -- \\
\hline $\begin{array}{l}\text { 1,2,3 Tri- } \\
\text { chloropropane }\end{array}$ & 0.02 & -- & -- & -- & -- & -- & - & -- & 0.13 & E. 07 & -- & -- & -- \\
\hline $\begin{array}{l}\text { Tetrachloro } \\
\text { ethylene }\end{array}$ & 0.05 & -- & -- & -- & -- & E.01 & -- & -- & -- & -- & -. & -- & -- \\
\hline $\begin{array}{l}\text { meta \& para } \\
\text { Xylene }\end{array}$ & 0.05 & -- & -- & -- & -- & -- & -- & -- & -- & E.007 & $\cdots$ & - & -- \\
\hline $\begin{array}{l}\text { 1,2 Dibromo- } \\
\text { chloropropane }\end{array}$ & 0.5 & E. 07 & E.07 & -- & -- & -- & $\cdots$ & - & -- & -- & -- & -- & -- \\
\hline Atrazine & 0.001 & E. 004 & E.004 & -- & E.006 & $-\infty$ & -- & - & E.002 & -- & -. & -- & -- \\
\hline Carbofuran & 0.12 & -- & E.002 & -- & -- & -- & -- & -- & -- & -- & -- & -- & -- \\
\hline $\begin{array}{l}\text { Desethyl } \\
\text { atrazine }\end{array}$ & 0.002 & E.006 & E.006 & - & E.005 & -- & -- & -- & E.004 & -- & -- & -- & $\cdots$ \\
\hline Dinoseb & 0.035 & 0.06 & 0.06 & -- & -- & -- & -- & -- & -- & -- & $-\cdot$ & - & -- \\
\hline Napropamide & 0.003 & 0.011 & 0.011 & -- & -- & -- & -- & -- & -- & -- & -- & -- & -- \\
\hline Oxamyl & 0.018 & 0.41 & 0.45 & -- & -- & -- & 1.2 & -- & 0.45 & 23 & -- & - & -- \\
\hline Simazine & 0.005 & 0.084 & 0.082 & -- & -- & -- & -- & -- & 0.021 & 0.021 & -- & - & -- \\
\hline Tebuthiuron & 0.01 & V.012 & V.012 & -- & -- & -- & -- & -- & -- & -- & -. & -- & -- \\
\hline
\end{tabular}

COMPOUNDS DETECTED IN SAMPLE WATER MOST LIKELY THE RESULT OF SAMPLING OR ANALYTICAL ARTIFACTS

\begin{tabular}{|c|c|c|c|c|c|c|c|c|c|c|c|c|c|}
\hline $\begin{array}{l}\text { Acetone (2-propa- } \\
\text { none) }\end{array}$ & 5.0 & -. & .. & -- & VE1.1 & VE1.0 & -- & VE0.8 & -- & VE0.6 & -- & E5 & E1. \\
\hline $\begin{array}{l}\text { Toluene (Methyl- } \\
\text { benzene) }\end{array}$ & 0.05 & VE.03 & VE.03 & VE.04 & VE.02 & VE.03 & VE.03 & VE.03 & VE.01 & VE.03 & VE.01 & --* & E.07 \\
\hline $\begin{array}{l}\text { 1,1,2-Trichloro- } \\
\text { 1,2,2-triflouro- } \\
\text { ethane (CFC-113) }\end{array}$ & 0.05 & VE.006 & -- & VE.01 & VE.01 & VE.01 & VE.02 & -- & -- & -- & VE.02 & 0.12 & E. 04 \\
\hline $\begin{array}{l}\text { 1,2,4-Trimethyl } \\
\text { Benzene }\end{array}$ & 0.05 & V.49 & V.37 & V.52 & V.25 & V. 20 & V.1 & V.30 & V.29 & V.44 & V.27 & 0.18 & 0.35 \\
\hline
\end{tabular}

* Toluene was reported at 0.005 in both laboratory procedure blanks associated with this sample and thus not estimated below the detection level. 
Table 6. Field measurements and concentrations of inorganic constituents in transboundary ground water from the Abbotsford-Sumas aquifer

[ $\mu \mathrm{S} / \mathrm{cm}$, microsiemens per centimeter; $\mathrm{mg} / \mathrm{L}$, milligrams per liter; $\mu \mathrm{g} / \mathrm{L}$, micrograms per liter; <, less than; --, no data]

\begin{tabular}{|c|c|c|c|c|c|}
\hline Water-quality constituent & $91-13$ & $91-15$ & $91-15$ & 94-LEH & $\begin{array}{l}94- \\
\text { SR-29 }\end{array}$ \\
\hline Date--month/day/1997 & $2 / 4$ & $2 / 4$ & $2 / 7$ & $2 / 7$ & $2 / 3$ \\
\hline Time & 0900 & 1300 & 0930 & 1300 & 1000 \\
\hline Water temperature, degrees Celsius & 11.5 & 11.6 & 11.5 & 9.8 & 10 \\
\hline Specific conductance, $\mu \mathrm{S} / \mathrm{cm}$ & 300 & 296 & 295 & 716 & 298 \\
\hline $\mathrm{pH}$, Standard units & 6.2 & 5.9 & 5.8 & 5.7 & 6.8 \\
\hline Dissolved oxygen, $\mathrm{mg} / \mathrm{L}$ & 5.2 & 8.4 & 8.0 & 10.3 & 7.2 \\
\hline Alkalinity, $\mathrm{mg} / \mathrm{L}$ as $\mathrm{CaCO}_{3}$ & 35 & 18 & 18 & 6.1 & 48 \\
\hline Calcium, $\mathrm{mg} / \mathrm{L}$ as $\mathrm{Ca}$ & 31 & 31 & 29 & 88 & 32 \\
\hline Magnesium, $\mathrm{mg} / \mathrm{L}$ as $\mathrm{Mg}$ & 7.8 & 6.5 & 6.5 & 17 & 8.7 \\
\hline Sodium, $\mathrm{mg} / \mathrm{L}$ as $\mathrm{Na}$ & 10 & 9.6 & 12 & 7.2 & 6.3 \\
\hline Potassium, $\mathrm{mg} / \mathrm{L}$ as $\mathrm{K}$ & 1.2 & 2.8 & 2.8 & 13 & 1.2 \\
\hline Bicarbonate, $\mathrm{mg} / \mathrm{L}$ as $\mathrm{HCO}_{3}$ & 42 & 21 & 22 & 7.4 & 57 \\
\hline Sulfate, $\mathrm{mg} / \mathrm{L}$ as $\mathrm{SO}_{4}$ & 34 & 28 & 28 & 41 & 16 \\
\hline Chloride, $\mathrm{mg} / \mathrm{L}$ as $\mathrm{Cl}$ & 13 & 14 & 14 & 28 & 6.5 \\
\hline Fluoride, $\mathrm{mg} / \mathrm{L}$ as $\mathrm{F}$ & $<0.1$ & $<0.1$ & $<0.1$ & $<0.1$ & $<0.1$ \\
\hline Silica, $\mathrm{mg} / \mathrm{L}$ as $\mathrm{Si}$ & 22 & 13 & 13 & 12 & 20 \\
\hline Sum of dissolved constituents, $\mathrm{mg} / \mathrm{L}$ (TDS) & 205 & 196 & 196 & 508 & 200 \\
\hline Residue on evaporation, mg/L (ROE) & 190 & 180 & 186 & 477 & 187 \\
\hline Ion Balance, percent difference & -2.39 & -1.37 & -1.28 & -1.17 & -2.66 \\
\hline Nitrite nitrogen, $\mathrm{mg} / \mathrm{L}$ as $\mathrm{N}$ & 0.02 & 0.02 & $<0.01$ & $<0.01$ & 0.02 \\
\hline Nitrate plus nitrite nitrogen, $\mathrm{mg} / \mathrm{L}$ as $\mathrm{N}$ & 15 & 18 & 18 & 67 & 18 \\
\hline Ammonia nitrogen, $\mathrm{mg} / \mathrm{L}$ as $\mathrm{N}$ & $<0.015$ & $<0.015$ & $<0.015$ & $<0.015$ & 0.07 \\
\hline Ammonia plus organic, $\mathrm{mg} / \mathrm{L}$ as $\mathrm{N}$ & $<0.2$ & $<0.2$ & $<0.2$ & $<0.2$ & $<0.2$ \\
\hline Phosphorus, $\mathrm{mg} / \mathrm{L}$ as $\mathrm{P}$ & $<0.01$ & $<0.01$ & $<0.01$ & $<0.01$ & $<0.01$ \\
\hline Phosphate, ortho, $\mathrm{mg} / \mathrm{L}$ as $\mathrm{P}$ & $<0.01$ & $<0.01$ & $<0.01$ & $<0.01$ & $<0.01$ \\
\hline Organic carbon, $\mathrm{mg} / \mathrm{L}$ as $\mathrm{C}$ & 1.1 & -- & -- & 0.8 & -- \\
\hline Antimony, $\mu \mathrm{g} / \mathrm{L}$ as An & $<1$ & $<1$ & $<1$ & $<1$ & $<1$ \\
\hline Arsenic, $\mu \mathrm{g} / \mathrm{L}$ as As & $<1$ & $<1$ & $<1$ & $<1$ & 1 \\
\hline Aluminum, $\mu \mathrm{g} / \mathrm{L}$ as $\mathrm{Al}$ & V4 & V12 & V13 & V27 & V3 \\
\hline Barium, $\mu \mathrm{g} / \mathrm{L}$ as $\mathrm{Ba}$ & 8 & 9 & 10 & 225 & 17 \\
\hline Beryllium, $\mu \mathrm{g} / \mathrm{L}$ as $\mathrm{Be}$, & $<1$ & $<1$ & $<1$ & $<1$ & $<1$ \\
\hline Bromide, $\mu \mathrm{g} / \mathrm{L}$ as $\mathrm{Br}$ & 30 & 30 & 20 & 30 & 1,100 \\
\hline Cadmium, $\mu \mathrm{g} / \mathrm{L}$ as $\mathrm{Cd}$ & $<1$ & $<1$ & $<1$ & $<1$ & $<1$ \\
\hline Chromium, $\mu \mathrm{g} / \mathrm{L}$ as $\mathrm{Cr}$ & 2 & 1 & $<1$ & $<1$ & 2 \\
\hline Cobalt, $\mu \mathrm{g} / \mathrm{L}$ as $\mathrm{Co}$ & $<1$ & $<1$ & $<1$ & $<1$ & $<1$ \\
\hline Copper, $\mu \mathrm{g} / \mathrm{L}$ as $\mathrm{Cu}$ & $<1$ & $<1$ & $<1$ & $<1$ & $<1$ \\
\hline Iron, $\mu \mathrm{g} / \mathrm{L}$ as $\mathrm{Fe}$ & $<3$ & $<3$ & $<3$ & 23 & $<3$ \\
\hline Lead, $\mu \mathrm{g} / \mathrm{L}$ as $\mathrm{Pb}$ & $<1$ & $<1$ & $<1$ & $<1$ & $<1$ \\
\hline Manganese, $\mu \mathrm{g} / \mathrm{L}$ as $\mathrm{Mn}$ & $<3$ & 3 & 3 & 11 & $<1$ \\
\hline Mercury, $\mu \mathrm{g} / \mathrm{L}$ as $\mathrm{Hg}$ & $<0.1$ & $<0.1$ & $<0.1$ & $<0.1$ & $<0.1$ \\
\hline Molybdenum, $\mu \mathrm{g} / \mathrm{L}$ as Mo & $<1$ & $<1$ & $<1$ & $<1$ & $<1$ \\
\hline Nickel, $\mu \mathrm{g} / \mathrm{L}$ as $\mathrm{Ni}$ & $<1$ & $<1$ & $<1$ & 1 & $<1$ \\
\hline Selenium, $\mu \mathrm{g} / \mathrm{L}$ as Se & $<1$ & $<1$ & $<1$ & $<1$ & $<1$ \\
\hline Silver, $\mu \mathrm{g} / \mathrm{L}$ as $\mathrm{Ag}$ & $<1$ & $<1$ & $<1$ & $<1$ & $<1$ \\
\hline Uranium, $\mu \mathrm{g} / \mathrm{L}$ as $\mathrm{U}$ & $<1$ & $<1$ & $<1$ & $<1$ & $<1$ \\
\hline $\mathrm{Zinc}, \mu \mathrm{g} / \mathrm{L}$ as $\mathrm{Zn}$ & V3 & V1 & $<1$ & V4 & $\mathrm{V} 1$ \\
\hline
\end{tabular}


Table 6. Field measurements and concentrations of inorganic constituents in transboundary ground water from the Abbotsford-Sumas aquifer--Continued

\begin{tabular}{|c|c|c|c|c|c|c|c|}
\hline $\mathrm{ABB} 2$ & $\mathrm{ABB} 4$ & ABB5 & FTC-1-24 & $\begin{array}{l}\text { BCME- } \\
\text { B-20 }\end{array}$ & $\begin{array}{l}\text { Equipment } \\
\text { blank }\end{array}$ & $\begin{array}{l}\text { Equipment } \\
\text { blank }\end{array}$ & $\begin{array}{l}\text { Laboratory } \\
\text { grade } \\
\text { water }\end{array}$ \\
\hline $2 / 5$ & $2 / 3$ & $2 / 6$ & $2 / 6$ & $2 / 5$ & $1 / 31$ & $2 / 10$ & $12 / 13$ \\
\hline 0900 & 1500 & 1000 & 1400 & 1200 & 1200 & 1200 & 0900 \\
\hline 11.0 & 12.5 & 10.6 & 8.5 & 8.0 & -- & -- & -- \\
\hline 179 & 391 & 324 & 420 & 405 & 2.0 & 2 & 1 \\
\hline 5.9 & 6.4 & 5.7 & 6.3 & 5.7 & -- & -- & -- \\
\hline 8.2 & 7.2 & 8.9 & 0.0 & 10.4 & -- & -- & -- \\
\hline 24 & 48 & 14 & 62 & 13 & 1.9 & 1.5 & - \\
\hline 15 & 44 & 35 & 49 & 47 & $<0.02$ & $<0.02$ & $<0.002$ \\
\hline 2.7 & 12 & 6.7 & 15 & 7.8 & $<0.01$ & $<0.01$ & $<0.001$ \\
\hline 13 & 8.8 & 5.7 & 8.8 & 5.3 & $<0.2$ & $<0.2$ & $<0.025$ \\
\hline 0.9 & 1.5 & 0.8 & 4.3 & 5.3 & $<0.1$ & $<0.1$ & -- \\
\hline 29 & 59.0 & 17.0 & 76.1 & 16 & -- & - & -- \\
\hline 19 & 27 & 19 & 130 & 19 & $<0.1$ & $<0.1$ & - \\
\hline 7 & 13 & 9.4 & 9.6 & 13 & $<0.1$ & $<0.1$ & -- \\
\hline$<0.1$ & $<0.1$ & $<0.1$ & $<0.1$ & $<0.1$ & $<0.1$ & $<0.1$ & -. \\
\hline 15 & 23 & 15 & 16 & 11 & $<0.01$ & $<0.01$ & $<0.02$ \\
\hline 121 & 266 & 219 & 270 & 274 & -- & -- & -- \\
\hline 114 & 248 & 210 & 273 & 255 & 3.0 & $<1$ & -- \\
\hline-1.38 & -0.47 & -5.19 & 0.36 & -2.59 & -- & -- & -- \\
\hline 0.02 & 0.02 & $<0.01$ & 0.01 & 0.03 & -. & -- & $<0.001$ \\
\hline 8.0 & 24 & 27 & $<0.05$ & 36 & -- & -- & $<0.05$ \\
\hline$<0.015$ & $<0.015$ & $<0.015$ & $<0.015$ & $<0.015$ & -- & -- & 0.019 \\
\hline$<0.2$ & $<0.2$ & $<0.2$ & $<0.2$ & $<0.2$ & -- & -- & - \\
\hline$<0.01$ & $<0.01$ & $<0.01$ & $<0.01$ & $<0.01$ & -- & -- & $<0.001$ \\
\hline$<0.01$ & $<0.01$ & $<0.01$ & $<0.01$ & $<0.01$ & -- & -- & -- \\
\hline-- & 0.5 & 0.5 & 1.0 & 0.5 & -- & -- & $-\cdot$ \\
\hline$<1$ & $<1$ & $<1$ & $<1$ & $<1$ & $<1$ & $<1$ & $<0.2$ \\
\hline$<1$ & $<1$ & $<1$ & 2 & $<1$ & $<1$ & $<1$ & -- \\
\hline V12 & V8 & V7 & V4.0 & V17 & 4 & 4 & $<0.3$ \\
\hline 20 & 13 & 6 & 36 & 131 & $<1$ & $<1$ & $<0.2$ \\
\hline$<1$ & $<1$ & $<1$ & $<1$ & $<1$ & $<1$ & $<1$ & $<0.2$ \\
\hline 80 & 30 & 30 & 30 & 20 & $<0.01$ & $<0.01$ & -- \\
\hline$<1$ & $<1$ & $<1$ & $<1$ & $<1$ & $<1$ & $<1$ & $<0.3$ \\
\hline$<1$ & 1 & $<1$ & $<1$ & $<1$ & $<1$ & $<1$ & $<0.2$ \\
\hline$<1$ & $<1$ & $<1$ & $<1$ & $<1$ & $<1$ & $<1$ & $<0.2$ \\
\hline$<1$ & $<1$ & $<1$ & $<1$ & $<1$ & $<1$ & $<1$ & $<0.2$ \\
\hline 11 & 53 & 13 & 920 & $<3$ & $<3$ & $<3$ & $<0.3$ \\
\hline$<1$ & $<1$ & $<1$ & $<1$ & $<1$ & $<1$ & $<1$ & $<0.3$ \\
\hline 2 & 2 & 3 & 130 & 5 & $<1$ & $<1$ & $<0.1$ \\
\hline$<0.1$ & $<0.1$ & $<0.1$ & $<0.1$ & $<0.1$ & $<0.1$ & $<0.1$ & -- \\
\hline$<1$ & $<1$ & $<1$ & $<1$ & $<1$ & $<1$ & $<1$ & $<0.2$ \\
\hline$<1$ & V1 & $<1$ & V4 & $<1$ & 2 & $<1$ & $<0.5$ \\
\hline$<1$ & $<1$ & $<1$ & $<1$ & $<1$ & $<1$ & $<1$ & -- \\
\hline$<1$ & $<1$ & $<1$ & $<1$ & $<1$ & $<1$ & $<1$ & $<0.2$ \\
\hline$<1$ & $<1$ & $<1$ & $<1$ & $<1$ & $<1$ & $<1$ & $<0.2$ \\
\hline $\mathrm{V}<1$ & $\mathrm{~V} 2$ & V1 & $\mathrm{V}<1$ & $\mathrm{~V}<1$ & 5 & 5 & $<0.5$ \\
\hline
\end{tabular}


Variability in analyte concentrations reported in the replicate samples was generally low. Because the duration between replicate samples was 3 days, the observed variations in the replicate data could be due to either short-term temporal variation in the groundwater quality, variations due to sampling and handling, or variations due to laboratory analysis. All constituents of the two samples, except dissolved organic carbon, were analyzed in different batch lots. Constituent concentrations for replicate samples are shown sideby-side in tables 5 and 6 , and show little variation. Identical laboratory results were reported for 95 percent of VOC and pesticide samples, 75 percent of trace-element samples, 71 percent of common ion and nutrient samples, and 20 percent of field parameters. In cases where different concentrations were reported, the relative percent difference between the samples was generally less than 10 percent.

Zinc, nickel, and aluminum were detected in equipment-blank samples at 5,2 , and $3 \mu \mathrm{g} / \mathrm{L}$, respectively. Nickel was detected in one sample at $4 \mu \mathrm{g} / \mathrm{L}$ and in one blank sample at $2 \mu \mathrm{g} / \mathrm{L}$. Zinc and aluminum have been shown to leach from the glass ampules used to store the nitric acid used in preserving trace-element samples and this leaching is suspected as the source of this contamination. The environmental concentrations of zinc were between less than 1 to $3.5 \mu \mathrm{g} / \mathrm{L}$; thus it is possible that zinc and nickel were not present in samples where they were reported. The reported concentrations of aluminum were between 3 to $27 \mu \mathrm{g} / \mathrm{L}$ and, because of the bias shown in the blank samples, are likely to be somewhat larger than actual concentrations present in ground water of the aquifer. The laboratory results of the zinc, nickel, and aluminum analyses were tabulated as reported but were flagged with a "V" to indicate potential bias.

Four VOCs that were detected in equipmentblank samples and ground-water samples were acetone (2-propanone), toluene (methylbenzene), 1,1,2trichloro-1,2,2-triflouroethane, and 1,2,4-trimethylbenzene. For three of these compounds, values estimated by the NWQL were below the MRL. The compound 1,2,4-trimethylbenzene was present at concentrations above the MRL in all ground-water samples and in both pre- and post-sampling equipment blanks. The concentrations in the two equipmentblank samples were 0.18 and $0.35 \mu \mathrm{g} / \mathrm{L}$, while concentrations in the ground-water samples were in a similar range, from 0.1 to $0.52 \mu \mathrm{g} / \mathrm{L}$. Because of this sampling bias, data for 1,2,4-trimethylbenzene is interpreted as not present in the ground water at concentrations greater than $1 \mu \mathrm{g} / \mathrm{L}$. 1,2,4-trimethylbenzene is a common component of gasoline. The laboratory results of these four VOCs were tabulated as reported but were flagged with a "V" to indicate potential bias.

\section{WATER-QUALITY RESULTS}

For each sample, 210 water-quality parameters were measured. Most of these had concentration values that were less than the MRL. The data are presented as two groups. Inorganic constituents including common ions, trace elements, nutrients, and the field parameters are the first group. Organic compounds are the second group, which includes 87 VOCs, 82 pesticides, and the $3 \mathrm{CFC}$ compounds (trichlorofluoromethane, CFC-11; dichlorodifluoromethane, CFC-12; and 1,1,2-trichloro-1,2,2-trifluoroethane, CFC-13). The MRL is the concentration at which a quantitative value for the concentration can be reliably determined. The laboratory analytical methods can generally detect the presence of a compound at concentrations smaller than the reporting level; however, analytical uncertainty is larger at these lower concentrations, and thus only qualitative estimates are reported in these instances. In instances when a compound was detected below the MRL, the laboratory provided an estimated concentration that is flagged with an " $E$ " to denote the estimated concentration. The "E" flag was also used for results in instances where matrix effects or a calibration curve was exceeded.

\section{Nutrients, Common Ions, and Trace Elements}

Nitrate concentrations ranged from $<0.05$ to $67 \mathrm{mg} / \mathrm{L}$ as nitrate nitrogen and were above the drinking water standard or guideline of $10 \mathrm{mg} / \mathrm{L}$ (U.S. Environmental Protection Agency, 1996; Health and Welfare Canada, 1993) at seven of nine wells. Nitrate contamination in this aquifer is well documented and these results were not unexpected. The concentrations of other common ions, trace elements, and nutrients in the Abbotsford-Sumas aquifer are generally small resulting in ground water having total dissolved solids typically less than $275 \mathrm{mg} / \mathrm{L}$. Calcium was the cation most prevalent in all of these ground-water samples, while the most prevalent anion was either nitrate, 
sulfate, or bicarbonate. Most trace-element concentrations were below the MRL. Zinc, nickel, and aluminum were detected in equipment blanks as discussed earlier and are estimated values. Aluminum, arsenic, chromium, manganese, nickel, and zinc were found at or near the MRL in several of the ground-water samples. All samples had concentrations of barium and bromide at concentrations greater than five times the MRLs, while most also had similar concentrations of iron and manganese. The largest trace-element concentration was $1,100 \mu \mathrm{g} / \mathrm{L}$ of bromide in well 94-SR-29.

The ground water is slightly acidic having $\mathrm{pH}$ values between 5.7 to 6.8 and is generally well oxygenated with dissolved oxygen concentrations typically greater than $7 \mathrm{mg} / \mathrm{L}$. The water quality in well FTC-1-24, which is located adjacent to Fishtrap Creek, is anomalous compared to the other wells. It has low concentrations of nitrate and dissolved oxygen, and generally has higher concentrations of iron, manganese, and sulfate.

\section{Pesticides and Volatile Organic Compounds}

Twenty-seven pesticides and volatile organic compounds (VOCs) were detected by the laboratory analysis (table 5). Only 23 of these detected compounds are likely present in the ground water of the Abbotsford-Sumas aquifer. Four of the detected VOCs are likely the result of sampling and analytical bias and were discussed in the previous section on data quality assessment. The concentrations of detected compounds ranged from 0.01 to $23 \mu \mathrm{g} / \mathrm{L}$. None of the reported concentrations of VOCs and pesticides (table 5) exceed the drinking water guidelines or standards for those compounds listed in tables 3 and 4 . Since most of the organic compounds that were analyzed were not detected, table 5 presents data only for those compounds with detectable concentrations.

Comparison of the concentrations of detected compounds in replicate samples from well 91-15 shows good agreement among replicates (table 5), indicating that variability due to sampling and analysis was small. Most of the compounds detected were at concentrations very near their detection limits. Of the 15 compounds detected in both samples, 10 had identical concentrations in the samples collected 3 days apart. The relative percent difference in concentrations for the five compounds with differing concentrations ranged from 2 to 28 percent. However, if 1,2,4-trimethylbenzene, which was thought to be an artifact of sampling, is excluded, then the range for the relative percent difference is 2 to 15 percent, averaging about 8 percent.

The number of detections of organic compounds in the ground-water samples was typically from three to eight compounds in each sample; however, in the deepest well, 94-SR-29, no organic compounds were detected. The most frequently detected organic compound was 1,2-dichloropropane (1,2-DCP), which was observed in all but the deepest well (94-SR-29) at concentrations ranging from 0.04 to $0.48 \mu \mathrm{g} / \mathrm{L}$, typically greater than two times the MRL. In the two wells with 1,2-DCP concentrations greater than $0.35 \mu \mathrm{g} / \mathrm{L}$, additional chlorinated propanes were also detected. Oxamyl was found in four wells at concentrations ranging from 0.41 to $23 \mu \mathrm{g} / \mathrm{L}$. Simazine, atrazine, and desethylatrazine were each present in three wells.

\section{Chlorofluorocarbons}

CFCs are synthetic organic compounds that are entirely of man-made origin. The primary use of these compounds is as a refrigerant, which began in the 1930's. The ultimate environmental fate of CFCs is release to the atmosphere, where CFCs can dissolve into precipitation that recharges aquifers. Atmospheric concentrations of CFCs have increased steadily from earliest detections until peak concentrations were reached in 1993 and 1994. Maximum atmospheric CFC concentrations for the period prior to 1997 are: CFC-11, 276 parts per trillion, volume (pptv); CFC-12, 544 pptv; and CFC-113, 84.8 pptv (Eurybiades Busenberg, U.S. Geological Survey, written commun., 1997). CFCs have been used to date some ground water recharged after 1940 based on the presumption that the source of the CFCs in the ground water is from atmospheric equilibration of CFCs present in the atmosphere at the time precipitation recharged the aquifer (Busenberg and Plummer, 1992). Concentrations larger than the maximum atmospheric concentrations indicate CFCs from sources in addition to atmospheric equilibration.

CFC concentrations were measured in water samples from seven wells and the equilibrium vapor phase concentrations, which can be compared to atmospheric concentrations, were computed following the procedures of Busenberg and Plummer (1992). 
Table 7. Concentration of chlorofluorocarbons in ground-water samples and calculated equalibrium vapor phase concentration

[mg/L, milligrams per liter; pg/kg, picograms per kilogram; pptv, parts per trillion by volume]

\begin{tabular}{|c|c|c|c|c|c|c|c|c|c|}
\hline \multirow[b]{2}{*}{ Well name } & \multirow[b]{2}{*}{$\begin{array}{l}\text { Sample } \\
\text { date }\end{array}$} & \multirow[b]{2}{*}{$\begin{array}{l}\text { Sample } \\
\text { time }\end{array}$} & \multirow[b]{2}{*}{$\begin{array}{l}\text { Dissolved } \\
\text { oxygen } \\
(\mathrm{mg} / \mathrm{L})\end{array}$} & \multicolumn{2}{|c|}{ CFC-11 } & \multicolumn{2}{|c|}{ CFC-12 } & \multicolumn{2}{|c|}{ CFC-13 } \\
\hline & & & & $\begin{array}{l}\text { Concen- } \\
\text { tration in } \\
\text { sample } \\
(\mathrm{pg} / \mathrm{kg})\end{array}$ & $\begin{array}{l}\text { Calcu- } \\
\text { lated } \\
\text { atmos- } \\
\text { pheric } \\
\text { concen- } \\
\text { tration } \\
\text { (pptv) }\end{array}$ & $\begin{array}{l}\text { Concen- } \\
\text { tration in } \\
\text { sample } \\
(\mathrm{pg} / \mathrm{kg})\end{array}$ & $\begin{array}{l}\text { Calcu- } \\
\text { lated } \\
\text { atmos- } \\
\text { pheric } \\
\text { concen- } \\
\text { tration } \\
\text { (pptv) }\end{array}$ & $\begin{array}{l}\text { Concen- } \\
\text { tration in } \\
\text { sample } \\
(\mathrm{pg} / \mathrm{kg})\end{array}$ & $\begin{array}{l}\text { Calcu- } \\
\text { lated } \\
\text { atmos- } \\
\text { pheric } \\
\text { concen- } \\
\text { tration } \\
\text { (pptv) }\end{array}$ \\
\hline \multirow[t]{3}{*}{$91-15$} & $2 / 4 / 97$ & $11: 23$ & 8.4 & 15,900 & 5,506 & 791 & 1,200 & 49.3 & 41.1 \\
\hline & & $11: 39$ & & 16,300 & 5,660 & 796 & 1,210 & 50.8 & 42.3 \\
\hline & & $11: 47$ & & 15,500 & 5,380 & 622 & 944 & 35.9 & 29.9 \\
\hline \multirow[t]{3}{*}{$91-13$} & $2 / 4 / 97$ & $13: 30$ & 5.2 & 24,000 & 8,310 & 3,290 & 5,000 & 182 & 151.4 \\
\hline & & $13: 45$ & & 23,900 & 8,290 & 3,330 & 5,050 & 189 & 158 \\
\hline & & $13: 53$ & & 23,000 & 7,980 & 3,000 & 4,550 & 99.7 & 83 \\
\hline \multirow[t]{2}{*}{ FTC-1-24 } & $2 / 27 / 97$ & $12: 30$ & $<0.1$ & 7.9 & 2.7 & 97.4 & 148 & 24.4 & 20.3 \\
\hline & & $12: 41$ & & 8.2 & 2.8 & 106 & 161 & 4.4 & 3.7 \\
\hline \multirow[t]{3}{*}{ ABB4 } & $2 / 3 / 97$ & $17: 00$ & 7.2 & 1,280 & 443 & 2,970 & 4,510 & 75 & 62.5 \\
\hline & & $17: 16$ & & 1,280 & 443 & 2,900 & 4,410 & 61.5 & 51.3 \\
\hline & & $17: 30$ & & 1,210 & 420 & 2,920 & 4,440 & 76.1 & 63.4 \\
\hline \multirow[t]{3}{*}{ ABB5 } & $2 / 6 / 97$ & $11: 30$ & 8.9 & 613 & 212 & 382 & 580 & 76.6 & 63.9 \\
\hline & & $11: 38$ & & 605 & 210 & 382 & 579 & 77.8 & 64.9 \\
\hline & & $11: 52$ & & 597 & 207 & 330 & 501 & 66.1 & 55.1 \\
\hline BCME- & $2 / 5 / 97$ & $14: 05$ & 10.4 & 676 & 234 & 464 & 703 & 157 & 130 \\
\hline B-20 & & $14: 30$ & & 663 & 230 & 430 & 649 & 11.2 & 9.3 \\
\hline \multirow[t]{3}{*}{ 94-SR-29 } & $2 / 3 / 97$ & $11: 25$ & 7.2 & 256 & 88.8 & 441 & 669 & 140 & 117 \\
\hline & & $11: 38$ & & 255 & 88.6 & 437 & 664 & 143 & 119 \\
\hline & & $12: 05$ & & 257 & 89 & 467 & 709 & 81.1 & 67.6 \\
\hline
\end{tabular}

These data are shown in table 7. Vapor phase concentrations for over half of the reported values are larger than the maximum atmospheric concentration, indicating the widespread presence of CFCs from nonatmospheric sources in the ground water. In one well, FTC-1-24, CFC concentrations were small, much less than the maximum concentrations, possibly indicating ground water older than 50 years. However, this well is also anoxic and recent studies have shown that CFCs can be microbially degraded under reducing conditions such as those present in this well. A subsequent sample from FTC-1-24 was analyzed for tritium, which produced a concentration of 26 tritium units indicating that the ground-water age was young, less than 50 years and confirming that the low concentrations of CFCs in this well were likely due to microbial degradation of the CFCs. Thus, the use of CFC concentrations for age-dating ground-water samples in the transboundary region of the Abbotsford-Sumas aquifer is unreliable.

\section{SUMMARY}

Ground-water quality and hydrogeologic data were collected from nine wells in the transboundary region of the Abbotsford-Sumas aquifer. Water-quality data included the concentrations of selected common ions, trace elements, pesticides, and volatile organic 
compounds, including three chlorofluorocarbons used to estimate residence times of ground water. The concentrations of common ions and trace elements were generally small resulting in low total dissolved constituents. However, the concentrations of nitrate were generally large: seven of nine wells yield water having concentrations of nitrate greater than both Canadian and United States drinking water guidelines and standards. Nitrate was the only water-quality constituent detected in these samples at concentrations above the Canadian and United States drinking water guidelines or standards. Twenty-seven organic compounds were detected in the ground-water samples with concentrations ranging from 0.01 to $23 \mu \mathrm{g} / \mathrm{L}$. Four of these compounds are thought to be affected by sampling or analytical bias. Three chlorofluorocarbons, CFC-11, CFC-12, and CFC-113, were detected, typically at concentrations greater than the maximum atmospheric concentrations, indicating additional sources of CFCs other than atmospheric equilibration and that CFCs would not be a reliable ground-water age-dating tool for this aquifer.

\section{REFERENCES CITED}

Associated Earth Sciences Inc., 1996, City of Sumas wellhead protection plan: Bellingham, Washington, Associated Earth Sciences Inc., variously paginated.

Busenberg, Eurybiades, and Plummer, L.N., 1992, Use of chlorofluoromethanes $\left(\mathrm{CCl}_{3} \mathrm{~F}\right.$ and $\left.\mathrm{CCl}_{2} \mathrm{~F}_{2}\right)$ as hydrologic tracers and age-dating tools--the alluvium and terrace system of central Oklahoma: Water Resources Research, v. 28 , p. 2,257-2,283.

Canadian Council of Ministers of the Environment, 1993, Canadian water quality guidelines Ottawa, Ontario, Environmental Quality Guidelines Division, Inland Waters Directorate, variously paginated.

Connor, Brooke F., Rose, Donna L., Noriega, Mary C., Murtagh, Lucinda K., and Abney, Sonja R., 1998, Methods of analysis by the U.S. Geological Survey National Water Quality Laboratory--determination of 86 volatile organic compounds in water by gas chromatography/mass spectrometry, including detections less than reporting limits: U.S. Geological Survey OpenFile Report 97-829, 78 p.

Cox, S.E., and Kahle, S.C., 1999, Hydrogeology, groundwater quality, and sources of nitrate in lowland glacial aquifers of Whatcom County, Washington, and British Columbia, Canada: Water-Resources Investigation Report 98-4195, 251 p., 5 pls.
Dasika, Raghava, 1996, Investigation into the distribution of non-point source nitrate in two unconfined aquifers and the role for carbon addition in the control of nitrate concentrations in ground water: Vancouver, University of British Columbia, PhD dissertation, $348 \mathrm{p}$.

Easterbrook, D.J., 1976, Geologic map of western Whatcom County, Washington: U.S. Geological Survey Miscellaneous Investigations Map I-854-B, 1 pl., scale 1:62,000.

Erickson, Denis, and Norton, Dale, 1990, Washington State agricultural chemicals pilot study: Washington State Department of Ecology, 90-46, 76 p.

Fishman, M.J., ed., 1993, Methods of analysis by the U.S. Geological Survey National Water Quality Laboratory-determination of inorganic and organic constituents in water and fluvial sediments: U.S. Geological Survey Open-File Report 93-125, 217 p.

Halstead, E.C., 1986, Ground water supply-Fraser Lowland, British Columbia: Environment Canada, National Hydrology Research Paper no. 26, 80 p.

Health and Welfare Canada, 1993, Guidelines for Canadian drinking water quality, fifth edition: Ottawa, Canada, Canadian Communication Group Publishing, K1A-0S9.

Koterba, M.T., Wilde, F.D., and Lapham, W.W., 1995, Ground-water data-collection protocols and procedures for the National Water-Quality Assessment Program-collection and documentation of water-quality samples and related data: U.S. Geological Survey Open-File Report 95-399, 113 p.

Liebscher, Hugh, Hii, Basil, and McNaughton, Duane, 1992, Nitrates and pesticides in the Abbotsford Aquifer, southwestern British Columbia: North Vancouver, British Columbia, Environment Canada, Inland Waters Directorate, $83 \mathrm{p}$.

Nowell, L.H., and Resek, E.A., 1994, Summary of national standards and guidelines for pesticides in water, bed sediment, and aquatic organisms and their application to water-quality assessments: U.S. Geological Survey Open-File Report 94-44, 115 p.

Pritt, J.W., and Raese, J.W., eds., 1995, Quality assurance/ quality control manual, National Water Quality Laboratory: U.S. Geological Survey Open-File Report 95-443, 35 p.

Rose, D.L., and Schroeder, M.P., 1995, Methods of analysis by the U.S. Geological Survey National Water Quality Laboratory--determination of volatile organic compounds in water by purge and trap capillary gas chromatography/mass spectrometry: U.S. Geological Survey Open-File Report 94-708, 26 p. 
Sandstrom, M.W., Wydoski, D.S., Schroeder, M.P., Zamboni, J.L., and Foreman, W.T., 1992, Methods of analysis by the National Water Quality Laboratory-determination of organonitrogen herbicides in water by solid-phase extraction and capillary-column gas chromatography/mass spectrometry with selected-ion monitoring: U.S. Geological Survey Open-File Report 91-519, $26 \mathrm{p}$.

Shelton, L.R., 1994, Field guide for collecting and processing stream-water samples for the National WaterQuality Assessment Program: U.S. Geological Survey Open-File Report 94-455, 42 p.

U.S. Environmental Protection Agency, 1996, Drinking water regulations and health advisories: U.S. Environmental Protection Agency, Office of Water, EPA 822-B-96-002, $17 \mathrm{p}$.

Werner, S.L., Burkhardt, M.R., and DeRusseau, S.N., 1996, Methods of analysis by the U.S. Geological Survey National Water Quality Laboratory--determination of pesticides in water by Carbopak-B solid-phase extraction and high-performance liquid chromatography: U.S. Geological Survey Open-File Report 96-216, 42 p.
Werner, S.L., and Johnson, S.M., 1994, Methods of analysis by the U.S. Geological Survey National Water Quality Laboratory--determination of selected carbamate pesticides in water by high-performance liquid chromatography: U.S. Geological Survey Open-File Report 93-650, $29 \mathrm{p}$.

White, A.F., Peterson, M.L., and Solbau, R.D., 1990, Measurement and interpretation of low levels of dissolved oxygen in ground water: Ground Water, v. 28 , no. 4 , p. $584-590$.

Wood, W.W., 1981, Guidelines for collection and field analysis of ground-water samples for selected unstable constituents: U.S. Geological Survey Techniques of Water-Resources Investigations, book 1, chap. D2, $24 \mathrm{p}$.

Zaugg, S.D., Sandstrom, M.W., Smith, S.G., and Fehlberg, K.M., 1995, Methods of analysis by U.S. Geological Survey National Water Quality Laboratory--determination of pesticides in water by $\mathrm{C}$ - 18 solid-phase extraction and capillary-column gas chromatography/mass spectrometry with selected ion monitoring: U.S. Geological Survey Open-File Report 95-181, 49 p. 
APPENDIX 
Appendix A. Logs of lithologic description obtained during drilling of observation-monitoring piezometers, in the Abbotsford-Sumas Aquifer, British Columbia

[--, no data]

Depth interval below land surface

Lithological description

(meters)

(feet)

Piezometer: 91-13; completed May 1991

Top soil and few gravel

Sand and gravel

$0.0-0.9$

$0.0-3.0$

Sandy gravel

$0.9-8.2$

$3.0-15.0$

Sand and gravel

$4.6-8.2$

$15.0-27.0$

Brown sand

$8.2-9.4$

$27.0-31.0$

Sandy gravel

$9.4-11.9$

$31.0-39.0$

Sand and gravel

$11.9-14.3$

$39.0-47.0$

Clay

$14.3-20.4$

$47.0-66.9$

Number 10 slot screen

$20.4-29.0$

$66.9-95.0$

$18.6-20.1$

$61.0-66.0$

Piezometer: 91-15; completed May 1991

Top soil and few gravel

Sand and gravel

$0.0-0.9$

$0.0-3.0$

Sandy gravel

$0.9-4.6$

$3.0-15.0$

$4.6-9.4$

$15.0-31.0$

Brown sand

$9.4-11.9$

$31.0-39.0$

Number 10 slot screen

$8.2-9.8$

$27.0-32.0$

\section{Piezometer: FTC-1-24; completed October 1991}

Gravel, cobble, and sand

$0.0-0.3$

$0.0-4.0$

Sand with clay, brown

$0.3-2.4$

$4.0-8.0$

Sand, medium to coarse, with gravel; greyish brown

$2.4-3.7$

$8.0-12.0$

Sand, medium to coarse with fine gravel; grey

$3.7-11.0$

$12.0-36.0$

Number 10 slot screen

$6.4-7.3$

$20.9-24.0$

\section{Piezometer: ABB2; completed March 1988}

Sand and fine to medium gravel

$0.0-1.8$

$0.0-6.0$

Sand and coarse gravel

$1.8-2.9$

$6.0-9.5$

Grey sand and cobbles ( 2.5 centimeters diameter)

$2.9-3.6$

$9.5-12.0$

Grey sand; fine to medium gravel

$3.7-5.8$

$12.0-19.0$

Grey sand; coarse gravel

$5.8-7.0$

$19.0-23.0$

Sand less silt; cobbles

$7.0-7.6$

$23.0-25.0$

Number 10 slot screen

$6.6-7.6$

$21.7-25.0$ 
Appendix A. Logs of lithologic description obtained during drilling of observation-monitoring piezometers, in the Abbotsford-Sumas Aquifer, British Columbia--Continued

Depth interval below land surface

Lithological description

(meters) (feet)

Piezometer: ABB4; completed March 1988

Sand and coarse gravel, oxidized

$0.0-0.9$

$0.9-6.9$

$6.9-11.0$

Grey sand; fine to coarse gravel

Sand; very fine gravel

Sand; coarse gravel

Silty sand and fine gravel

Silty sand and very fine gravel

Grey sand and coarse gravel

Grey sand; very fine gravel

Grey sand; fine to coarse gravel

Sand and gravel; cobbles

Sand and very fine gravel to coarse gravel

Sand and coarse gravel

Sand and gravel; some cobbles

Number 10 slot screen

Piezometer: ABB5; completed March 1988

Clayey sand and gravel; oxidized

Silty brown sand; slight clay

Grey sand and coarse gravel

Grey sand and fine gravel; cobbles

Grey sand and pea gravel

Sand and coarser gravel; cobbles

Grey sand and gravel; no pebbles

Number 10 slot screen

Piezometer: BCME-B-20; complete 1988

Top soil

Sand and gravel with lenses of sand

Number 10 slot screen

\section{Piezometer: 94 LEH; completed 1994}

Top soil

Sand and gravel

$0.0-0.3$

$0.0-0.6$

$0.6-10.7$

$3.0-5.5$

Number 10 slot screen
$0.3-22.9$

$8.2-9.8$
$0.0-2.0$

$2.0-35.0$

$10.0-18$

$0.0-3.0$

$3.0-22.5$

$22.5-36.0$

$36.0-47.5$

$47.5-48.0$

$48.0-56.5$

$56.5-57.0$

$57.0-63.5$

$63.5-67.0$

$67.0-80.5$

$80.5-81.5$

$81.5-86.0$

$86.0-93.5$

$93.5-96.0$

$92.7-96.0$

$0.0-12.0$

$12.0-17.5$

$17.5-21.0$

$21.0-25.0$

$25.0-26.0$

$26.0-28.0$

$28.0-29.0$

$25.7-29.0$

$0.0-4.0$

$4.0-75$

$27.0-32.0$ 
Appendix A. Logs of lithologic description obtained during drilling of observation-monitoring piezometers, in the Abbotsford-Sumas Aquifer, British Columbia--Continued

Depth interval below land surface

Lithological description

(meters) $\quad$ (feet)

\section{Piezometer: 94-SR-29; completed 1994}

Brown sandy clay

Brown sand and gravel

$0.0-2.7$

$0.0-9.0$

Grey sand with clay lenses

$2.7-3.7$

$9.0-12.0$

Silty sand and gravel

$3.7-5.5$

$12.0-18.0$

Brown clay and sand

$5.5-6.1$

$18.0-20.0$

Sandy brown clay with pebbles

$6.1-14.9$

$20.0-49.0$

Sandy grey clay with pebbles

$14.9-22.9$

$49.0-75.0$

Sand and gravel

$22.9-24.7$

$75.0-81.0$

Dirty coarse sand with clay lenses

$24.7-29.0$

$81.0-95.0$

Number 10 slot screen

$29.0-29.6$

$95.0-97.0$

-.

-. 